\title{
3000 years of environmental change at Zaca Lake, California, USA
}

\section{Theodore Dingemans ${ }^{1}$, Scott A. Mensing ${ }^{1 *}$, Sarah J. Feakins ${ }^{2}$, Matthew E. Kirby ${ }^{3}$ and Susan R. H. Zimmerman ${ }^{4}$}

' Department of Geography, University of Nevada, Reno, Reno, NV, USA

${ }^{2}$ Department of Earth Sciences, University of Southern California, Los Angeles, Los Angeles, CA, USA

${ }^{3}$ Department of Geological Sciences, California State University, Fullerton, Fullerton, CA, USA

${ }^{4}$ Lawrence Livermore National Laboratory, Center for Accelerator Mass Spectrometry, Livermore, CA, USA

\section{Edited by:}

Valentí Rull, Botanical Institute of Barcelona (IBB-CSIC-ICUB), Spain

\section{Reviewed by:}

Anne Elisabeth Bjune, Uni Research Ltd., Norway

Debra Willard, US Geological

Survey, USA

*Correspondence:

Scott A. Mensing, Department of Geography, University of Nevada, 201 Mackay Science, Reno, NV 89557, USA

e-mail: smensing@unr.edu
Climatic variations of the last few millennia can reveal patterns of variability beyond that recorded by the instrumental record. The purpose of this paper is to answer the question: is there evidence for periods of persistent drought in the vicinity of Zaca Lake, Santa Barbara County, California, and can the mechanisms which drive them be identified? In this study we use pollen, sediments, and hydrogen isotopes from leaf wax to generate a 3000 year record of vegetation and climate along the Southern California coast. We identify a multi-centennial scale drought between 2700 and 2000 cal yr BP in Zaca Lake, corroborating evidence from across the Great Basin and extending the regional spread of this multi-centennial drought to Southern California. Wetter conditions in the northwest during this period indicate that the modern ENSO precipitation dipole also occurred during this persistent drought. Today this dipole is associated with La Niña conditions and we note a coincidence with intriguing evidence for a change in ENSO dynamics from marine records in the tropical Pacific. This dry period is remarkably persistent and has important implications for understanding the possible durations of drought conditions in the past in California. In addition, we find evidence for 3 warm periods between 1350 and $650 \mathrm{cal}$ yr $\mathrm{BP}$ which are identified in the record by the presence of the algae Pediastrum boryanum var. boryanum. The latter two of these periods, dating from 1070-900 and 700-650 cal yr BP correspond to droughts during the Medieval Climatic Anomaly identified in other records. A period of high Salix percentages and high pollen concentration from 500 to $250 \mathrm{cal}$ yr BP represents the wettest period of the record and coincides with the Little Ice Age. An increase in Pinus and Quercus pollen found in the last 100 years of the record is a result of known planting and fire suppression by the forest service.

Keywords: drought, Holocene, leaf wax D/H ratio, paleoclimate, pollen, Southern California

\section{INTRODUCTION}

The potential for persistent century-long droughts in California has been well documented. Submerged stumps in lakes and rivers have been interpreted as evidence for epic droughts between 1000 and $600 \mathrm{cal} \mathrm{yr} \mathrm{BP} \mathrm{(Stine,} \mathrm{1994).} \mathrm{Additional} \mathrm{research} \mathrm{has} \mathrm{supported}$ the interpretation of a dry (Meko et al., 2001; Cook et al., 2004; Herweijer et al., 2007; MacDonald et al., 2008; Kleppe et al., 2011) or warm (Graumlich, 1993; Scuderi, 1993; Millar et al., 2006) climate during this period, confirming that extended droughts are a part of California's climatic history and raising the concern that should such conditions return in the future, it would have serious economic consequences for the region. Despite the interest in developing a better understanding of the climate history of California, there are still a limited number of high-resolution paleoclimate studies that span the last few millennia, a period sufficiently long to identify droughts of a century or more in time. In the dry climate of California, natural lakes are rare outside of mountain environments, and the number of paleoclimate reconstructions remains sparse for much of the state, especially in Southern California, where the majority of the population lives. Therefore, it is critical to take advantage of each natural site available for expanding our understanding of the long-term climate history of California.

A handful of important paleoenvironmental studies in the region have been published (Figure 1). Holocene reconstructions of stream flow and lake level change have been developed using grain size and geochemistry at Lake Elsinore and Lower Bear Lake, Southern California (Kirby et al., 2007, 2010, 2012). A chronology of lake level was developed for Tulare Lake, central California by locating paleo-shorelines (Negrini et al., 2006). In the central California Coast environmental conditions were reconstructed using pollen and charcoal going back 3300 years at Skylark Pond (Cowart and Byrne, 2013). Just north of the San Francisco Bay Area pollen and charcoal were used to create a 6200-year record from Glenmire, Point Reyes Peninsula (Anderson et al., 2013). Previously at Zaca Lake, Mensing (1998) developed a pollen and 


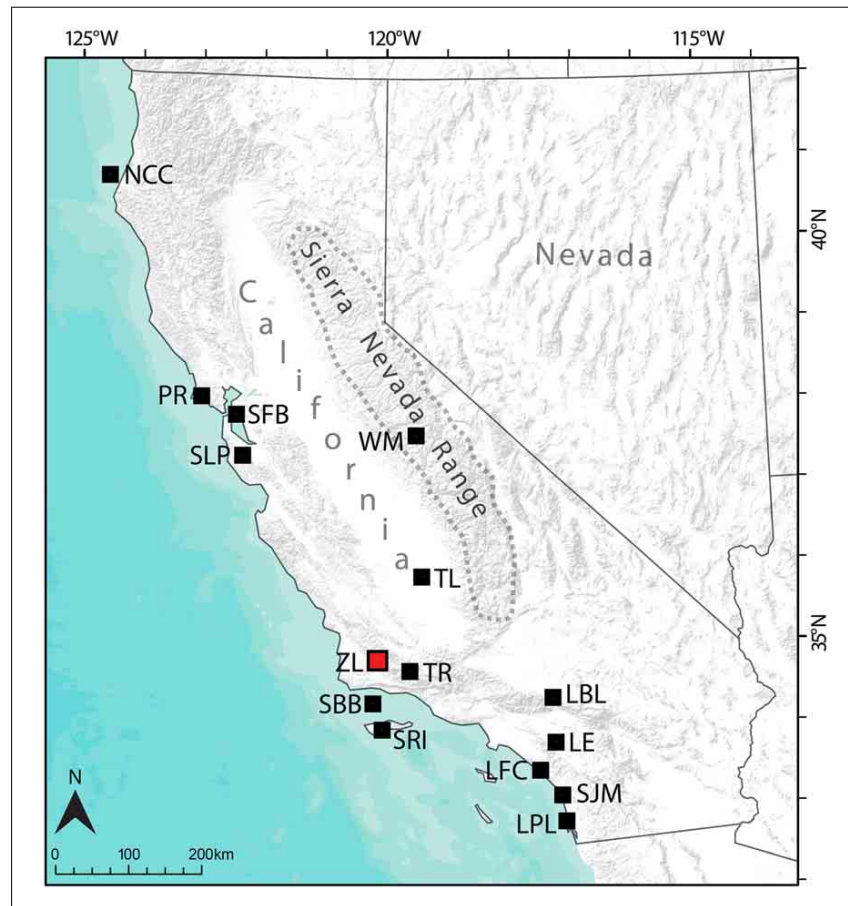

FIGURE 1 | Map of California and Nevada with locations referenced in the text. The geographic extent of the Sierra Nevada Range is marked by the dashed line. Zaca Lake location marked with a red square, other sites referred to in the text marked with black squares. LBL (Lower Bear Lake), LE (Lake Elsinore), LFC (Las Flores Creek), LPL (Los Peñasquitos Lagoon), NCC (North coast California), PR (Point Reyes), SBB (Santa Barbara Basin), SFB (San Francisco Bay), SJM (San Joaquin Marsh), SLP (Skylark Pond), SRI (Santa Rosa Island), TL (Tulare Lake), TR (Transverse Ranges), WM (Wawona Meadow).

charcoal record from a $3 \mathrm{~m}$ core, and Feakins et al. (2014) identified changes in precipitation source over the past 3000 years using fluctuations in the leaf wax $\mathrm{D} / \mathrm{H}$ ratio from the same core used in this study.

Pollen and charcoal in sediment cores recovered from tidal estuaries, marshes and the SBB have been used to reconstruct fire and vegetation along coastal California. Changes in moisture and vegetation were reconstructed over the past 7000 years at San Joaquin Marsh (Davis, 1992), and over the past 5000 years on Santa Rosa Island (Cole and Liu, 1994), at Los Peñasquitos Lagoon (Cole and Wahl, 2000), and at Las Flores Creek (Anderson and Byrd, 1998). High resolution records of vegetation and climate change from the SBB span the last 600 years (Mensing, 1998; Mensing et al., 1999) as well as the Holocene (Heusser, 1978) and late Pleistocene (Heusser and Sirocko, 1997). Freshwater input into the San Francisco Bay over the last 3000 years has been reconstructed from sediment cores (Byrne et al., 2001; Malamud-Roam et al., 2006).

Tree rings play an important role in providing high-resolution records of precipitation and temperature over the past few centuries. A 600-year tree-ring reconstruction of precipitation for the Transverse Ranges, near Zaca Lake, was developed from big-cone spruce (Pseudotsuga macrocarpa) (Haston and Michaelsen, 1994). Unfortunately, long-lived tree species appropriate for building lengthy chronologies are absent from low elevations across most of central and Southern California, limiting the usefulness of dendrochronology in the region.

High resolution reconstructions of sea surface temperature (SST), upwelling, and the strength of the California Current exist for the Holocene (Pisias, 1978; Kennett and Kennett, 2000; Roark et al., 2003; Fisler and Hendy, 2008) and at higher resolution for the last 1000-2000 years (Field and Baumgartner, 2000; Zhao et al., 2000; Barron et al., 2010; Li et al., 2011). Efforts to correlate marine records with terrestrial climate during the past 1000 years have been moderately successful (Pisias, 1979; Huguet et al., 2007; Grelaud et al., 2009), but relationships, such as cool SST associated with dry terrestrial conditions, weaken further back in time (Kennett et al., 2007). In addition, interpretations differ as to how conditions such as SST and upwelling changed over time, complicating our understanding of marine conditions during the late Holocene. New terrestrial paleoecologic records may help to clarify the paleoclimatic history of the region.

The purpose of this paper is to answer the question: is there evidence for periods of persistent drought in the vicinity of Zaca Lake, Santa Barbara County, California, and can the mechanisms which drive them be identified? In this study we use pollen and sediments, to generate a 3000 year record of vegetation and climate along the Southern California coast. We then compare the pollen data with a previously published leaf was $\delta \mathrm{D}$ record (Feakins et al., 2014) reconstructed from the same Zaca Lake core to infer potential source regions for precipitation. Zaca Lake is ideal for creating a high resolution paleoecologic record because it has a rapid and constant sedimentation rate that allows for frequent sampling at regular time intervals. The Zaca Lake watershed is small and records local vegetation. In addition, the study site is located only $55 \mathrm{~km}$ from the Santa Barbara Basin (SBB), a varved coastal marine basin with an extensive paleoclimatic record, allowing for comparison between terrestrial and marine environments.

\section{STUDY AREA}

Zaca Lake $\left(34^{\circ} 46^{\prime} \mathrm{N}, 120^{\circ} 2^{\prime} \mathrm{W}\right)$ is a rare low-elevation $(730 \mathrm{~m})$ natural lake formed by a Quaternary landslide (Hall, 1981a), located in the San Rafael Mountains, $50 \mathrm{~km}$ from the Pacific Ocean and $200 \mathrm{~km}$ northwest of Los Angeles (Figure 2). The lake covers 8.2 ha with a maximum depth of $\sim 12 \mathrm{~m}$, and a small, steep sided catchment of 900 ha. Complete mixing occurs once a year, generally in January and February, and otherwise anaerobic conditions persist below $\sim 7 \mathrm{~m}$ water depth (Caponigro, 1976). The lake sill is $\sim 9 \mathrm{~m}$ above modern lake level, making outflow rare.

Southern California has a Mediterranean climate and receives almost no summer precipitation. Mean annual precipitation at Zaca Lake is $\sim 740 \mathrm{~mm}$ (PRISM data, 1895-2011; Daly et al., 2008), which comes primarily from a handful of major winter storms typically originating in the north Pacific (Cayan and Rhoads, 1984; Feakins et al., 2014).

The lake lies within a belt of folded Monterey Miocene Formation bedrock, a sedimentary rock of marine origin rich in calcium carbonate (Behl, 1999). Zaca Lake has an actively flowing spring complex located $\sim 2 \mathrm{~km}$ upstream, characterized 


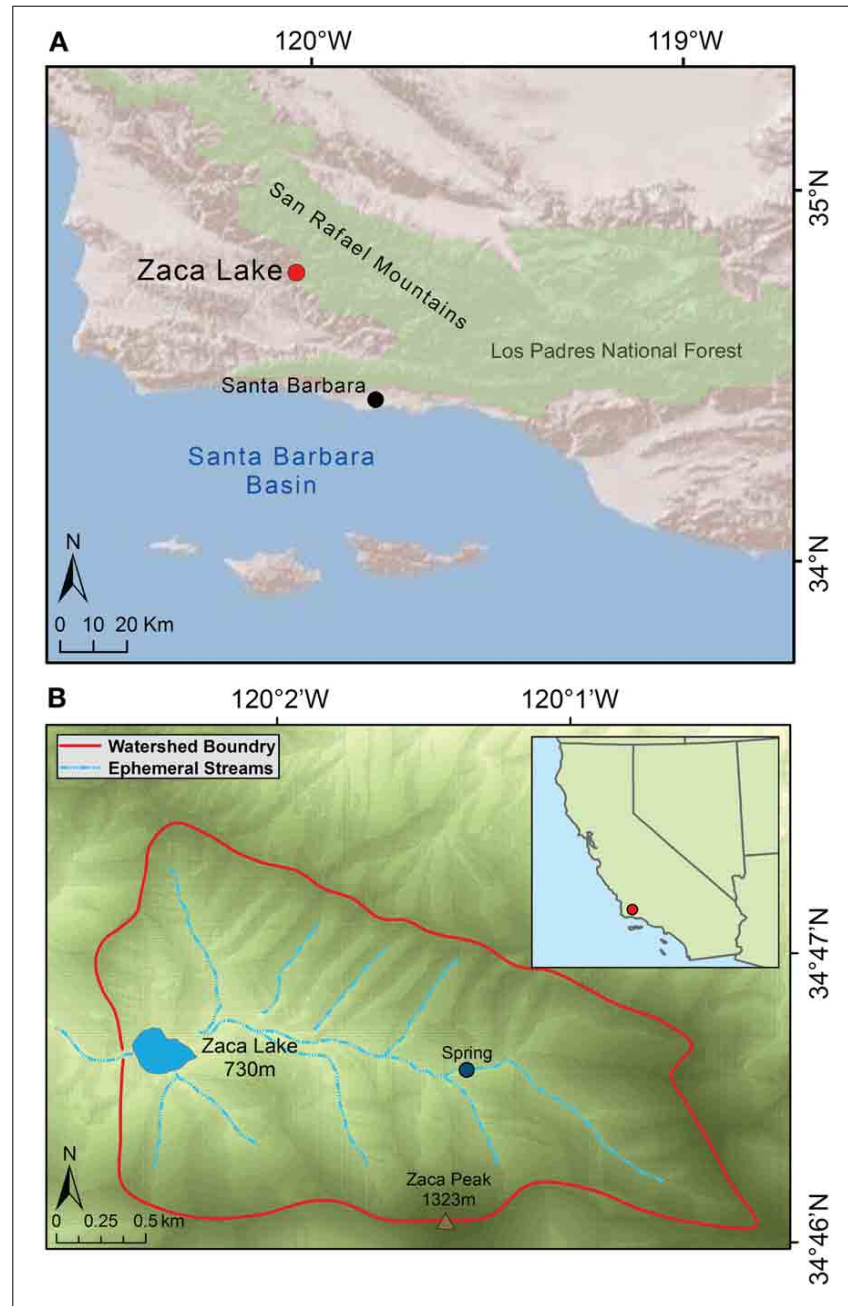

FIGURE 2 | Map of Zaca Lake location. (A) Santa Barbara Region (B) Zaca Lake watershed.

by large calcium carbonate tufa deposits (Ibarra et al., 2014). Currently no surface water reaches the lake except during rain events.

Vegetation in the Zaca Lake watershed can be broadly separated into three categories: pine-oak woodlands, chaparral, and riparian. Pine oak woodlands are dominated by coast live oak (Quercus agrifolia) and coulter pine (Pinus coulteri) but ponderosa pine ( $P$. ponderosa), gray pine ( $P$. sabiniana), interior live oak (Q. wislizenii), canyon live oak (Q. chrysolepis) and valley oak, (Q. lobata) are present. Small stands of big-cone spruce (Pseudotsuga macrocarpa) and incense cedar (Calocedrus decurrens) grow at higher elevations. Pines and oaks are found throughout the Zaca Lake watershed, except on south facing, dry, rocky or steep slopes, where chaparral dominates. Chaparral, including California lilac (Ceanothus spp.), manzanita (Arctostaphylos spp.), Yucca spp., sage (Salvia spp.), and California sagebrush (Artemisia californica) grow on exposed slopes and in openings between the pines and oaks. Riparian species include sycamore (Platanus racemosa), big leaf maple (Acer macrophyllum), California bay (Umbellularia californica), and willow (Salix spp.). Rushes (Juncus spp.), tules (Scirpus spp.), and cattails (Typha spp.) grow along the lake shoreline.

Pollen in the sedimentary record of Pinus and Quercus are most likely from the two most common tree species in the watershed, coulter pine (Pinus coulteri) and coast live oak (Q. agrifolia). Platanus is California sycamore ( $P$. racemosa) the only species of Platanus in the region. Numerous species of Salix (willow) grow in the region and these have not been identified to the species level. Rhamnaceae includes a number of shrubs common to chaparral in the region, including Adenostema fasciculatum, Heteromoles arbutifolia, Ceanothus spp., Cercocarpus spp., and Prunus spp. (Mensing, 1993). Artemisia is from California sagebrush (A. californica). Herbaceous species of Asteraceae are abundant in the region, and commonly associated with disturbed or open habitats. Eriogonum (Polygonaceae) include a diverse set of species in California and the pollen cannot be identified below the genus level. Amaranthaceae and Poaceae are not typically identifiable beyond the family level.

The modern vegetation may not be representative of the site during the pre-Euro-American period. Many of the mature coulter pines result from a massive planting operation beginning $\sim \mathrm{AD}$ 1900 (Norris and Norris, 1994). Additionally, historical photographs from the turn of the 20th century suggest that there were many fewer trees at that time (Mensing, 1998). The increase in forest cover over the past century is likely the result of a combination of fire suppression and organized planting.

\section{METHODS}

\section{CORE RECOVERY AND SUBSAMPLING}

An $8.5 \mathrm{~m}$ core (core Z-1C) was recovered in July 2009, and the core is thoroughly described in Feakins et al. (2014). The coring team used a combination of Bolivia and Livingstone piston corers for successive drives from a four-way-anchored, small boatbased coring operation provided by the National Lacustrine Core Facility (LacCore). Coring efforts ceased when further drives could not be obtained with the equipment available. Core Z-1C was stored in a cold room at California State University, Fullerton (CSUF). Subsamples for pollen analysis were taken at CSUF in 2011 and 2013.

\section{DATING}

The chronologic control for the Z-1C core comes from 16 radiocarbon dates of terrestrial macrofossils as well as additional exotic pollen and ${ }^{137} \mathrm{Cs}$ events (as reported in Feakins et al., 2014). A total of 21 radiocarbon dates were obtained on materials found in the core (Table 1). Of the 21 radiocarbon dates obtained, 16 are used for age control and 5 were excluded as discussed below. Two dates were discounted as they appear to represent incorporation of pre-aged material (by ca. 5000 and $1000{ }^{14} \mathrm{C}$ yrs; CAMS\# 147070 and 147074, respectively); these outliers are not discussed further. In addition we discount three dates on very fine and delicate organic fragments from $778.5,800.5$, and $806.5 \mathrm{~cm}$ depths each yielding identical ages $100{ }^{14} \mathrm{C}$ yrs younger than the overlying date at $642 \mathrm{~cm}$ depth which shows no evidence of reworking (Table 1). This sequence of dates raises the question of instantaneous deposition or increased erosion of terrestrial sediment from 808 to $648 \mathrm{~cm}$ in the core, for which we find no stratigraphic 
Table 1 | Dates obtained for developing the age model.

\begin{tabular}{|c|c|c|c|c|c|c|c|c|}
\hline Type & Depth (cm) & CAMS\# & Material dated & In age model & Mass of $\mathrm{C}(\mathrm{mg})$ & $d^{13} C(\% o)$ & ${ }^{14} \mathrm{C}$ Years BP & $\sigma$ \\
\hline Historical & 42.5 & n.a. & Cs peak & Yes & n.a. & n.a. & n.a. & 0 \\
\hline${ }^{14} \mathrm{C}$ & 95.5 & 144842 & Twigs & Yes & 1.07 & -25.00 & 180 & 35 \\
\hline Pollen & 135 & n.a. & Erodium FO & Yes & n.a. & n.a. & n.a. & 14 \\
\hline${ }^{14} \mathrm{C}$ & 164.5 & 144843 & Bark and twigs & Yes & 0.71 & -25.00 & 325 & 35 \\
\hline${ }^{14} \mathrm{C}$ & 244.5 & 147067 & Single twig & Yes & 0.35 & -25.00 & 550 & 30 \\
\hline${ }^{14} \mathrm{C}$ & 244.5 & 147068 & Single twig & Yes & 0.15 & -25.00 & 440 & 40 \\
\hline${ }^{14} \mathrm{C}$ & 244.5 & 147070 & Stem & $\mathrm{No}^{\mathrm{a}}$ & 0.05 & -25.00 & 5210 & 110 \\
\hline${ }^{14} \mathrm{C}$ & 275.5 & 144845 & Twigs & Yes & 1.01 & -25.00 & 725 & 30 \\
\hline${ }^{14} \mathrm{C}$ & 305.5 & 144846 & Twig, bark, leaf & Yes & 0.58 & -25.00 & 835 & 30 \\
\hline${ }^{14} \mathrm{C}$ & 444.5 & 144848 & Root, grass, leaf & Yes & 0.20 & -25.00 & 1335 & 35 \\
\hline${ }^{14} \mathrm{C}$ & 525.5 & 144849 & Wood & Yes & 1.16 & -25.00 & 1595 & 30 \\
\hline${ }^{14} \mathrm{C}$ & 577.5 & 144850 & Leaf, grasses & Yes & 0.96 & -25.00 & 1840 & 30 \\
\hline${ }^{14} \mathrm{C}$ & 585.5 & 147074 & Stems, charcoal & $\mathrm{No}^{\mathrm{a}}$ & 0.17 & -25.00 & 2370 & 40 \\
\hline${ }^{14} \mathrm{C}$ & 642 & 144851 & Seed, organics & Yes & 0.80 & -25.00 & 2040 & 30 \\
\hline${ }^{14} \mathrm{C}$ & 778.5 & 144852 & Organic fibers & $\mathrm{No}{ }^{b}$ & 0.23 & -25.00 & 1905 & 35 \\
\hline${ }^{14} \mathrm{C}$ & 800.5 & 144853 & Twigs and bark & $\mathrm{No}^{\mathrm{b}}$ & 0.41 & -25.00 & 1905 & 30 \\
\hline${ }^{14} \mathrm{C}$ & 806.5 & 144854 & Charcoal, twigs & $\mathrm{No}{ }^{b}$ & 0.18 & -25.00 & 1910 & 35 \\
\hline${ }^{14} \mathrm{C}$ & 839.5 & 147076 & Stems, charcoal & Yes & 0.129 & -25.00 & 2680 & 40 \\
\hline
\end{tabular}

CAMS\#, sample identification number from measurements at the Center for Accelerator Mass Spectrometry, Lawrence Livermore National Laboratory (LLNL). No : identified as an outlier by the age model and not used. No : identified as an outlier by the authors. $S / W$ interface, core top sample that captured the sediment water interface without disturbance. FO, first occurrence. Historical, historical markers are the ${ }^{137}$ Cs peak (1963), measured by D. Hammond at the University of Southern California (USC). Pollen, historical dates from invasive species. Pollen counts (by L. Reidy at UC Berkeley) in this core are assigned dates based on the first appearance (Mensing and Byrne, 1998) of Erodium cicutarium pollen (1755-1760 AD) identified in varved sediments from a marine core recovered from the Santa Barbara Basin, and Eucalyptus pollen based on planting date (Norris and Norris, 1994) and estimated maturity. Age uncertainty on pollen dates are estimates.

evidence briefly described as follows. The base of the unit is not erosional and contains sub-cm scale laminae that are concordant across the basal section. The grain size data lack a sharp basal contact and indicate a gradual change in sediment texture across the base of the sediment unit (Kirby et al., under review). Geochemistry is inconsistent with a terrestrial input: we find low LOI $550^{\circ} \mathrm{C}$, low $\mathrm{C}_{\text {org }} / \mathrm{N}_{\text {total }}$ (Kirby et al., under review), low magnetic susceptibility, and low LOI $950^{\circ} \mathrm{C}$. Each of these suggest diminished terrestrial inputs including reduced transport of terrestrial organics and magnetic minerals into the lake. Analysis of littoral cores spanning the past $600 \mathrm{cal} \mathrm{yr} \mathrm{BP}$ indicate LOI $950^{\circ} \mathrm{C}$ values in excess of $70 \%$, littered with abundant charaphytic stems and gastropod shells (Rubi, 2013). We find no evidence for this material having been transported in an event to the lake depocenter. Finally, variable $\delta \mathrm{D}$ values suggest that leaf waxes were transferred into the lake over time, reflecting changes in water source. From these various structural and sedimentological data, we conclude that the three dates $(778.5,800.5$, and $806.5 \mathrm{~cm}$ ) are unreliable and thus are not included in the age model. The remaining dates were input into the R-based statistical program BACON v2.2 (Blaauw and Christen, 2011) to develop an initial age model using the IntCal13 calibration curve (Reimer et al., 2013). BACON uses a Bayesian approach to accumulation histories by separating the core into many sections and then estimating accumulation rate for each through millions of Markov Chain Monte Carlo iterations. The program calculates the probability density function for all dates as well as identifying outliers, ${ }^{14} \mathrm{C}$ dates that lie outside of the $95 \%$ confidence interval. Outliers likely represent ${ }^{14} \mathrm{C}$ ages on reworked material out of stratigraphic context. Two outliers were identified (244.5 and $585.5 \mathrm{~cm}$ ) and these ages were also removed from the age model calculations. The final Bayesian age model for Z-1C was calculated using the dates identified in Table 1 with the following parameters: estimated accumulation rate set to 5 year $/ \mathrm{cm}$ to make calculating accumulation rate faster and maximum depth set $873 \mathrm{~m}$, so that ages were calculated for the total length of the $\mathrm{Z}-1 \mathrm{C}$ core. Remaining elements used default parameters.

\section{SEDIMENT AND POLLEN ANALYSIS}

Core Z-1C was sampled at $1 \mathrm{~cm}$ contiguous intervals, and losson-ignition analysis was performed at the CSUF Paleoclimatology and Paleotsunami Laboratory. Total organic matter (TOM) and 
total carbonate (TC) were determined by weighing samples after $2 \mathrm{~h}$ in a furnace at $550^{\circ} \mathrm{C}$ and then reweighing them after an additional $2 \mathrm{~h}$ at $950^{\circ} \mathrm{C}$ (Dean, 1974; Heiri et al., 2001).

Subsamples were processed for pollen at the University of Nevada, Reno (UNR) Palynology Laboratory. Sample sizes were $0.625 \mathrm{~cm}^{3}$ volume. After analysis of the initial samples we noted low pollen concentrations in certain sections of the core. In these sections, subsequent analysis used $1.25 \mathrm{~cm}^{3}$ volume to increase total pollen and facilitate counting. All samples were processed using standard pollen preparation procedures (Faegri and Iversen, 1985). A known quantity of an exotic tracer (Lycopodium spores) was added. Following potassium hydroxide $(\mathrm{KOH})$ treatment, samples were sieved using a $125 \mu \mathrm{m}$ mesh to remove the large organic fraction. Processed samples were mounted on glass microscope slides using silicon oil and counted at $400 \times$ magnification. Pollen was identified to the lowest possible taxonomic level using the UNR Palynology Laboratory reference collection and published keys (Moore and Webb, 1978; Kapp et al., 2000).

Samples from the Z-1C core were counted at intervals of $\sim 20 \mathrm{~cm}$. We were unable to count samples between 651 and $691 \mathrm{~cm}$ depth due to poor pollen preservation and low concentration. A total of 400 terrestrial pollen grains were counted per slide except for 12 samples between a depth of 641 and $801 \mathrm{~cm}$. In this section, due to low pollen concentration, we counted 300 terrestrial grains per slide. Pollen zones were interpreted from a constrained single-link dendrogram created using ConSLink in the PolPal plotting program (Nalepka and Walanus, 2003). Data input included the six most common taxa plus indeterminate pollen, total pollen concentration, \% TOM, and \% TC.

Three surface samples were collected from the land around Zaca Lake to process pollen samples from the soil surface and examine the type of degradation for comparison with the fossil degraded pollen. These samples were treated with $5 \% \mathrm{KOH}$ for $4 \mathrm{~h}$, sieved using a $500 \mu \mathrm{m}$ mesh, and then processed in the same manner as the Z-1C pollen samples. Surface samples were scanned to assess the type and extent of pollen deterioration.

Analyzing pollen preservation is an established component of palynological studies (Tweddle and Edwards, 2010). Changes in vegetation (Tipping, 1987), transport (Delcourt and Delcourt, 1980; Wilmshurst and McGlone, 2005), and depositional environments (Hall and Valastro, 1995; Park et al., 2010) have been shown to affect pollen preservation, and understanding the causes and variability associated with preservation is key to interpreting the Zaca Lake record.

An important component of pollen preservation is identification of the type of pollen deterioration. There is no accepted standard for the quantification of pollen deterioration (Twiddle and Bunting, 2010), however, the most common methodology is one first proposed by Cushing (1967) and subsequently modified in studies by Birks (1970), Delcourt and Delcourt (1980), and Lowe (1982). Typically, this methodology divides pollen deterioration into categories, the most common being: corroded, degraded, crumpled, or broken (Twiddle and Bunting, 2010). Typically corrosion and degradation are caused by chemical weathering (oxidation) and result in loss of surface features, so that shape may be maintained, but grains cannot be positively identified. Crumpling and breaking result from mechanical weathering and change the shape of pollen grains, making them difficult to identify. The type of pollen deterioration is important because it can help determine the source, transport mechanisms, and depositional environment of the pollen (Delcourt and Delcourt, 1980; Lowe, 1982; Wilmshurst and McGlone, 2005).

Variation in structure and composition of pollen grains affects pollen preservation (Hall, 1981b), with some taxa being more resistant to degradation than others. Studies have shown that sporopollenin content and exine thickness are the most important factors for determining resistance to degradation (Havinga, 1967; Campbell, 1999). The two taxa most resistant to degradation are Asteraceae and Pinus (Havinga, 1984). High Asteraceae pollen percentage has been used as an indicator of poorly preserved pollen (Tomescu, 2000). Similarly, studies from western North America have noted the increase in Pinus percentage in samples with poor pollen preservation (Hall, 1981b; Hall and Valastro, 1995; Park et al., 2010). Pollen grains that can be identified even when damaged or degraded, such as Pinus, Amaranthaceae, or Asteraceae account for higher percentages in poorly preserved sediments (Hall, 1981b; Tomescu, 2000). Finally, sections in a record with poorly preserved pollen tend to be characterized by low pollen concentration rates potentially both because of loss of pollen as well as lower pollen productivity during dry periods (Delcourt and Delcourt, 1980; Park et al., 2010).

\section{LEAF WAX D/H}

Plant leaf waxes were extracted from the sediments of Z-1C and analyzed for hydrogen isotopic composition by Feakins et al. (2014). Hydrogen isotopes (D, H) in water undergo large massdependent fractionations associated with phase changes at all stages of the water cycle (e.g., condensation), resulting in the potential to trace hydrological processes (Gat, 1996) including differentiating precipitation by storm track (Friedman et al., 2002). It has been shown that plants record the $\mathrm{D} / \mathrm{H}$ ratio of precipitation systematically, although there are variations in the fractionation between water and wax molecules with plant type (Sachse et al., 2012). For this reason, plant leaf wax reconstructions of precipitation isotopes can benefit greatly from the information provided by paired pollen studies (Feakins, 2013). Here we re-evaluate previously published leaf wax $\mathrm{D} / \mathrm{H}$ records with our pollen data, to test whether reconstructions of precipitation isotopic variability are robust to vegetation changes (i.e., vary independently) and, if they do vary independently, to integrate the evidence from both proxies to discern the atmospheric circulation regimes that may have led to drought. We report hydrogen isotopic $(\mathrm{D} / \mathrm{H})$ compositions in standard $\delta \mathrm{D}$ notation in permil (\%o) units.

Warm and dry conditions are expected to be associated with D-enriched precipitation due to the temperature of condensation and post-condensation evaporative processes (Buenning et al., 2013), and vice versa for cold and wet conditions. In addition wetter conditions, specifically with more antecedent rainout, lead to more D-depleted precipitation (Lee and Fung, 2008).

In addition pollen ratios document variations in plant types growing in the catchment, providing constraints on community change. Ecological change may influence $\delta \mathrm{D}$ values based on changing apparent fractionations $\left(\varepsilon_{\text {wax } / w}\right)$ between the $\delta \mathrm{D}$ values 
of precipitation $\left(\delta \mathrm{D}_{\text {water }}\right)$ and the $\delta \mathrm{D}$ values of leaf wax lipids $\delta \mathrm{D}_{\text {wax }}$ where

$$
\varepsilon_{w a x / w}=\frac{\delta_{w a x}+1}{\delta_{w}+1}-1
$$

which has been shown to vary with plant type globally (Sachse et al., 2012). Several of the dominant species in the catchment have been characterized in terms of the $\delta \mathrm{D}$ values of the $n$-alkanoic acids by Feakins et al. (2014), as well as the $\delta$ D values of $n$-alkanes in several species from sites across California (Feakins and Sessions, 2010).

We note that the leaf wax reconstruction is at higher resolution than the pollen record because of sampling intervals and also the slower response time of plant life-span (on the order of 1-100 year) vs. leaf life-span (1-3 years). We therefore evaluate the low frequency features of the $\delta \mathrm{D}_{\text {wax }}$ record. Here we take a paired pollen-leaf wax approach to account for ecological and environmental conditions which may modulate the hydrological interpretations of the changing $\delta \mathrm{D}$ values downcore. Having accounted for wet/dry effects and species change modulation of $\mathrm{D} / \mathrm{H}$ records, we can then proceed to better explore the hydrological significance of the $\mathrm{D} / \mathrm{H}$ variations, which may include changes in moisture source region, with more D-depleted storms originating from the midlatitude North Pacific and more D-enriched storms originating from the subtropical North Pacific (Friedman et al., 2002; McCabe-Glynn et al., 2013), with the exception of pineapple express type storms, or atmospheric rivers (Dettinger, 2011) that originate near Hawaii, which may also contribute D-depleted precipitation (Coplen et al., 2008).

\section{RESULTS}

The basal age of the Z-1C core age model (Figure 3) is about 3000 cal yr BP (calendar years before present, present $=$ AD1950). The

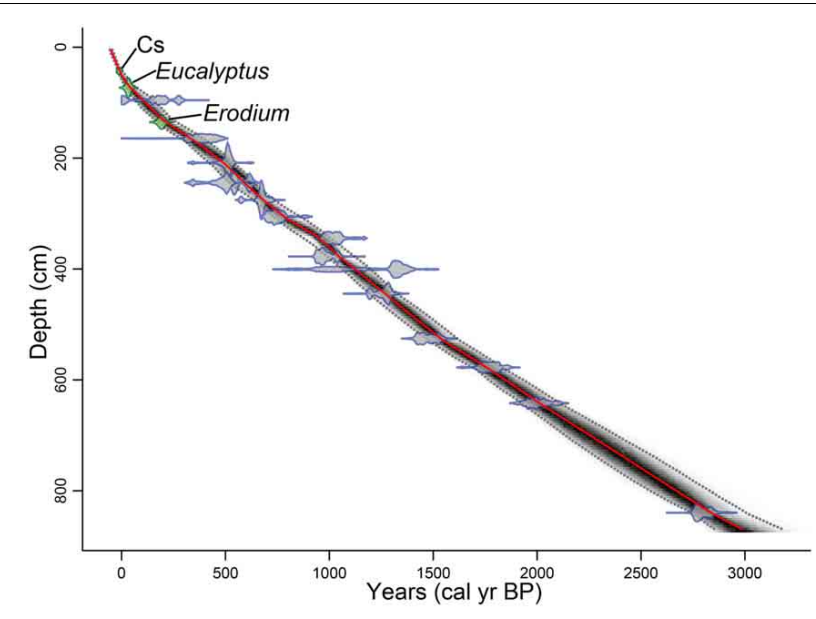

FIGURE 3 | Age model for core Z1C. Best fit age for each depth (red line), the probability calculation (darker color indicates more likely calendar age), and $95 \%$ confidence interval (gray dotted line). Calibrated ${ }^{14} \mathrm{C}$ dates (blue), and first occurrence of exotic pollen and ${ }^{137} \mathrm{Cs}$ peak (green), all with their 2-sigma error range. sediment accumulation rate for the top $1 \mathrm{~m}$ is $5.8 \mathrm{~mm}$ year ${ }^{-1}$, while the sedimentation rate for the remaining $7.7 \mathrm{~m}$ of core is $2.7 \mathrm{~mm}_{\text {year }}{ }^{-1}$. The overall sedimentation rate is $2.9 \mathrm{~mm}_{\text {year }}{ }^{-1}$ and the bottom $7.7 \mathrm{~m}$ of the core has a nearly linear sedimentation rate.

Total core length was $873 \mathrm{~cm}$. A complete description of core sedimentology is provided in Kirby et al. (under review). The core consists of sections of alternating dark gray, black, or brown layers; light brown homogenous units of varying thickness; occasional layers $(1-3 \mathrm{~cm}$ thick) of sandy silts or terrestrial organic material, including small organic fragments and charcoal; and, infrequent laminations of carbonate $(\sim 1 \mathrm{~mm})$. Based on whole core sedimentological averages, the lake is dominated by inorganic, non-carbonate clastic sedimentation (mean = $81.0 \%, \sigma=12.7 \%$ ) with contributions from chemical and biogenic carbonates (mean $=9.3 \%, \sigma=11.0 \%$ ) and allochthonous and autochthonous organic matter (mean $=10.1 \%, \sigma=3.3 \%)$. The grain size analysis of the clastic component indicates the sediments are dominated by clayey silts with variable sand contributions.

A total of 54 strata were counted for pollen. Samples were taken approximately every $20 \mathrm{~cm}$ through the length of the core. In sections where greater detail was desired, additional samples were taken at $5-10 \mathrm{~cm}$ intervals. In one section with very poor pollen preservation, samples were $40 \mathrm{~cm}$ apart. Time between samples was as follows: from 5 to $40 \mathrm{~cm}$ (16-170 years); 48 years between samples from 869 to $691 \mathrm{~cm}$ depth $(2970$ to $2200 \mathrm{cal} \mathrm{yr}$ BP), 170 years between samples from 691 to $651 \mathrm{~cm}$ depth $(2200$ to $2040 \mathrm{cal} \mathrm{yr} \mathrm{BP),} 60$ years between samples from 651 to $81 \mathrm{~cm}$ depth (2040 to $60 \mathrm{cal} \mathrm{yr} \mathrm{BP} \mathrm{[1890} \mathrm{AD]),} \mathrm{and} 24$ years between samples from $81 \mathrm{~cm}$ depth to the surface (60 cal yr BP [1890 AD] to the present).

Twenty-three terrestrial pollen taxa were identified. Aquatic palynomorphs included Cyperaceae and the algae Pediastrum boryanum var. boryanum (Figure 4). Pinus, Quercus, Platanus, and Asteraceae occur in consistently high percentages (Figures 5, 6). Additionally, Salix and Artemisia make up a high percentage in at least one sample.

The majority of the pollen comes from high pollen producing arboreal taxa (Pinus and Quercus) or plants growing in close proximity to the lake. Big-cone spruce (Pseudotsuga macrocarpa), incense cedar (Calocedrus decurrens), and big leaf maple (Acer macrophyllum) are restricted to the upper reaches of the watershed today and only show up in very low quantities. Additionally, chaparral are low pollen producers and are likely under-represented.

Zone 5, from 870 to $805 \mathrm{~cm}$ depth (2970 to $2700 \mathrm{cal} \mathrm{yr} \mathrm{BP})$, is characterized by low total pollen concentration $(<45,000$ grains $\mathrm{cm}^{-3}$ ), high percentages of Asteraceae (30\%), and high percentages of indeterminate grains (15\%). Platanus is variable (between 3 and 44\%); Pinus levels are below average (5\% vs. 9\% overall) and Quercus levels are average (17\% vs. 19\% overall). The sediments between 870 and $853 \mathrm{~cm}$ depth are light brown with low $\%$ TC (4\%) and \%TOM (8\%). The sediments between 852 and $808 \mathrm{~cm}$ contain intermittent bands of dark gray to black, light gray to brown, and narrow bands of light brown material high in \% TC (above 20\%). 


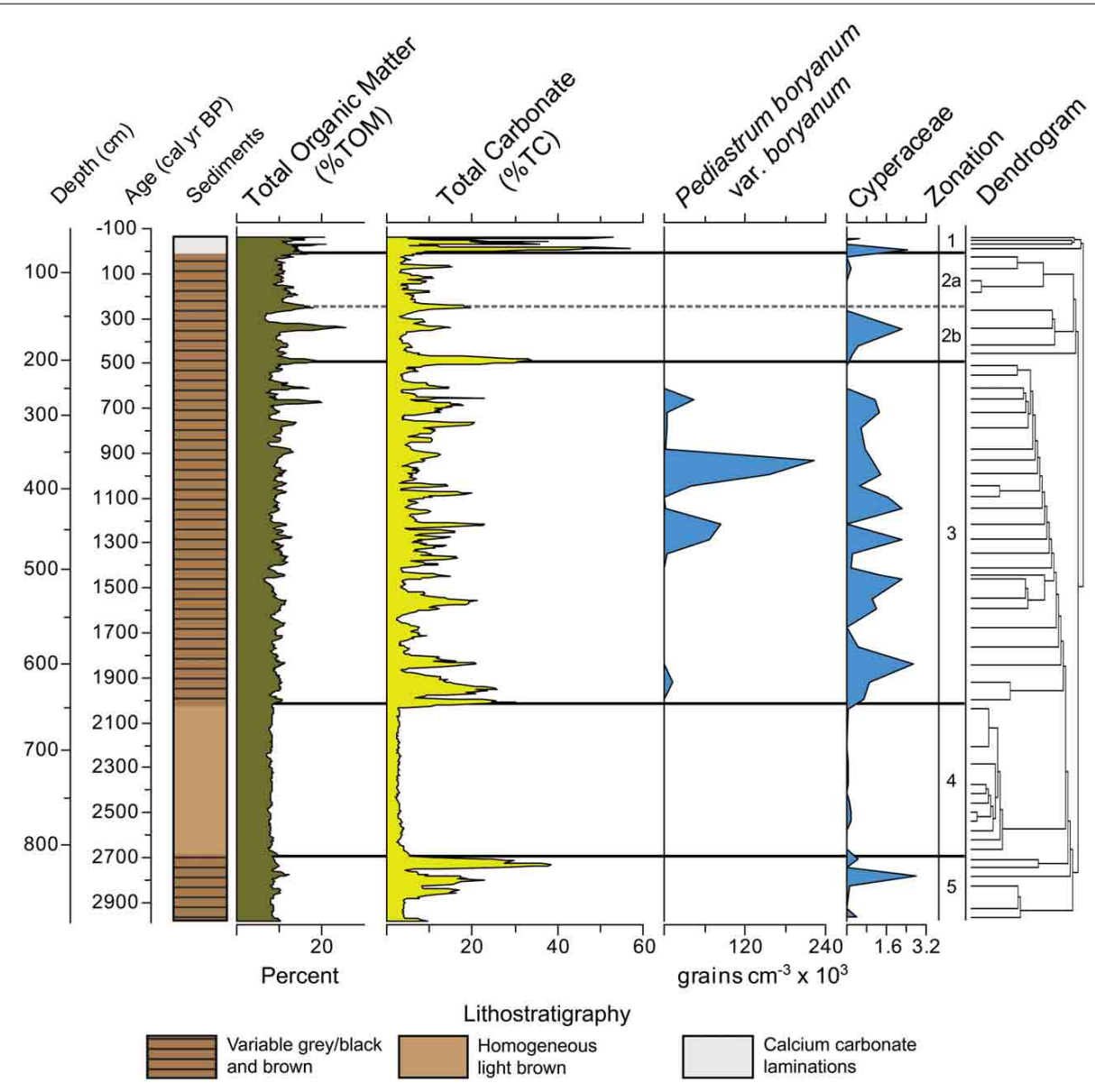

FIGURE 4 | Zaca Lake core lithostatigraphy, Total Organic Matter (\%TOM), Total Carbonate (\%TC), and concentration of aquatic palynomorphs. TOM and TC smoothed using a 5 point average. Pollen zones were interpreted from a constrained single-link dendrogram.

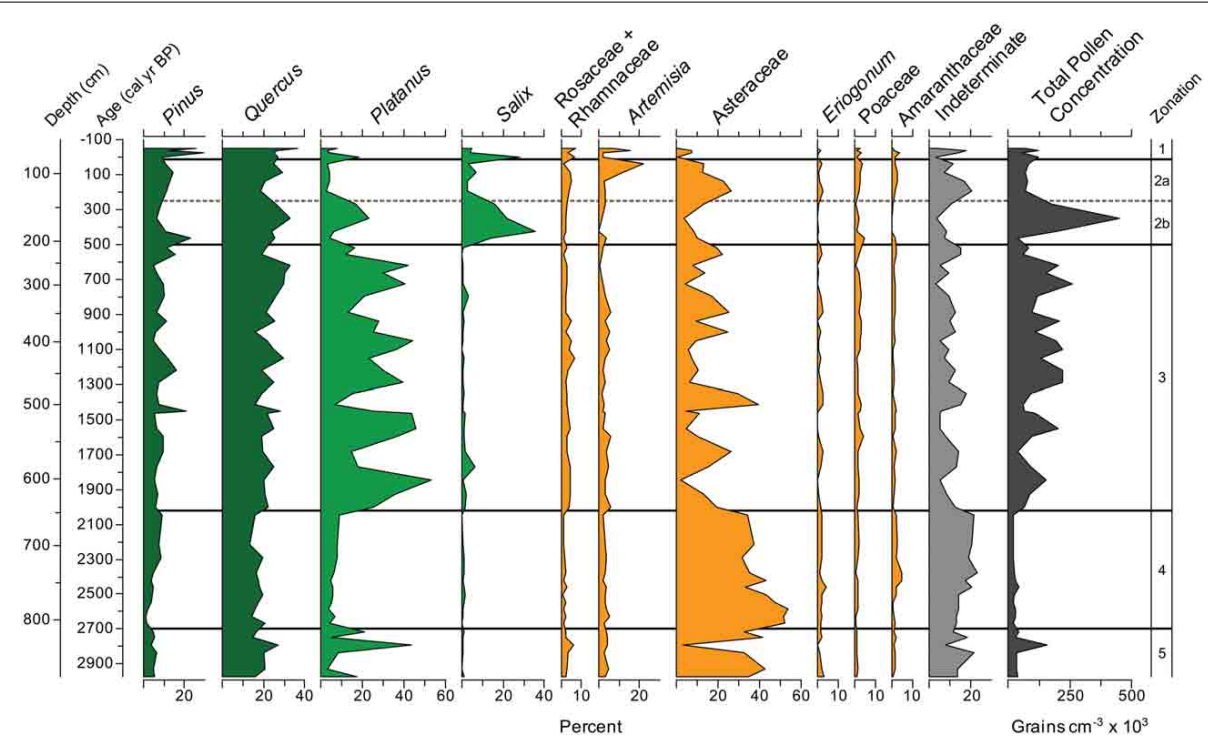

FIGURE 5 | Zaca Lake pollen percentages for the ten most common taxa plotted with indeterminate grains and total pollen concentration. 


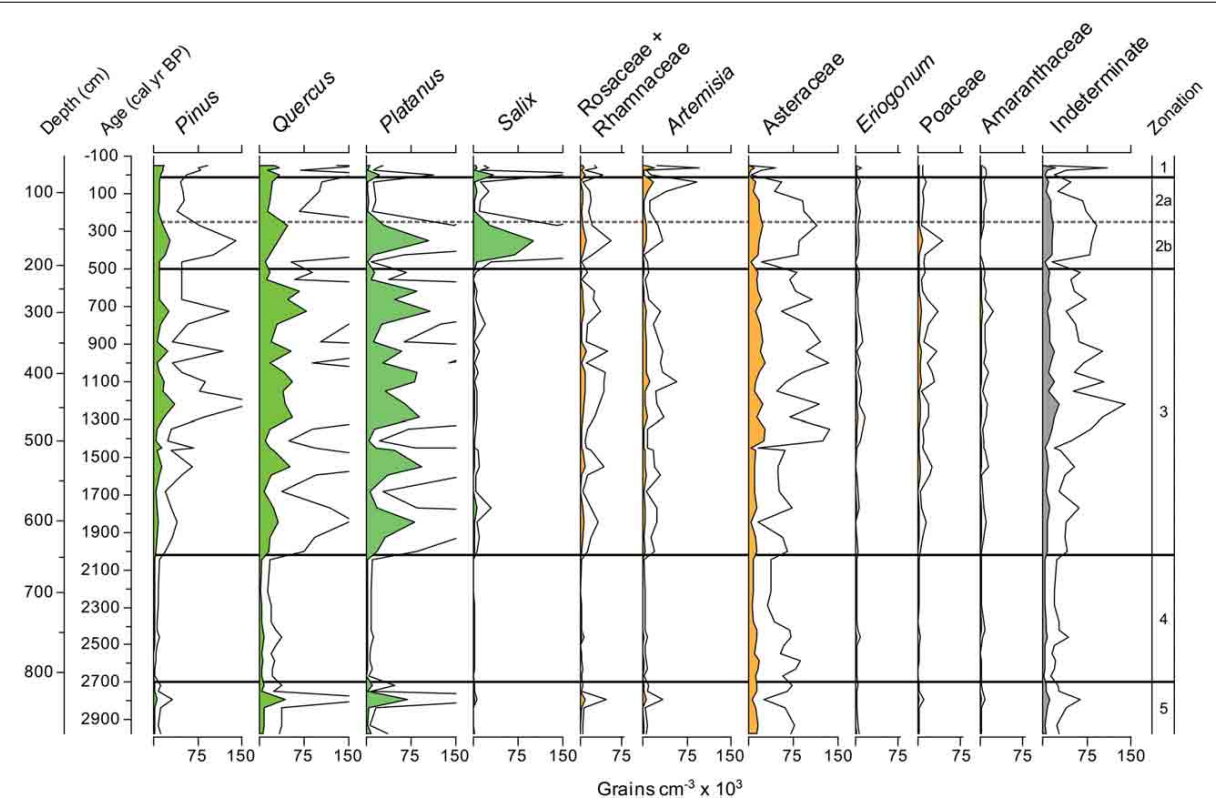

FIGURE 6 | Zaca Lake pollen concentration for the ten most common taxa plotted with indeterminate grains. Lines above the pollen percentages represent $3 \mathrm{X}$ exaggeration.

Zone 4, from 805 to $645 \mathrm{~cm}$ depth (2700 to $2020 \mathrm{cal} \mathrm{yr} \mathrm{BP})$ is characterized very high percentages of both Asteraceae ( $42 \%$ average) and indeterminate grains (17\%), and the lowest total pollen concentration in the record. Asteraceae is one of the most resistant pollen types to oxidation and degradation (Havinga, 1984), and the combination of high Asteraceae, high indeterminate, and low concentration is a signature for poor pollen preservation, described more fully below. Pinus, Platanus, and Quercus are all at their lowest levels for the entire record. This is the most uniform section of the core, considering sediment color (light brown material extending $>150 \mathrm{~cm}$ between 805 and $645 \mathrm{~cm}$ depth); TC (3\% average), TOM ( $8 \%$ average), and total pollen concentration are all low.

Zone 3 from 645 to $210 \mathrm{~cm}$ depth $(2020$ to $500 \mathrm{cal} \mathrm{yr} \mathrm{BP})$ is characterized by high variability in the percentages of Asteraceae, Platanus, and total pollen concentration. Platanus also reaches its highest average percentage of any zone (29\%). Quercus and Pinus show increased variability and make up a higher overall percentage than in Zones 4 and 5 (32\% vs. 23\% in zones 4 and 5). TC is variable with low values $(\sim 4 \%)$ associated with light brown sediment. P. boryanum var. boryanum is found between 1350 and 1150, 1070, and 900, and 700 and $650 \mathrm{cal} \mathrm{yr} \mathrm{BP.} \mathrm{Cyperaceae,}$ largely absent from Zone 4 is abundant in Zone 3.

Zone $2 \mathrm{~b}$, from 210 to $145 \mathrm{~cm}$ depth ( 500 to $250 \mathrm{cal} \mathrm{yr} \mathrm{BP}$ ), is characterized by the highest levels of Salix found in the record, reaching $40 \%$, as well as the highest overall pollen concentration (216,000 grains $\left.\mathrm{cm}^{-3}\right)$, indicating well preserved pollen. TC is moderate to low and TOM reaches its highest levels $(20 \%)$ in the record around $350 \mathrm{cal} \mathrm{yr} \mathrm{BP.} \mathrm{Zone} 2 \mathrm{a}$, from 145 to $60 \mathrm{~cm}$ depth (250 to $15 \mathrm{cal}$ yr BP [1935 AD]), is characterized by a period of moderate pollen preservation, with low percentages of Salix (4\%), moderate Asteraceae (19\%), and low Platanus (3\%). Pollen concentration decreases and Artemesia increases to its highest levels $(22 \%)$ at $\sim 30$ cal yr BP (1920 AD). TC is generally low (4-10\%).

Zone 1 , from 60 to $0 \mathrm{~cm}$ depth $(15 \mathrm{cal} \mathrm{yr} \mathrm{BP}$ [1935 AD] to present), is characterized by extreme variability, with spikes in Salix, Artemesia, and Platanus all found in the top samples of the record. Pinus and Quercus are more common than in any other zone in the record (19\% and $29 \%$ zonal average, respectively). Pollen concentration is average or slightly below average. The sediments in zone 1 are characterized by very fine laminations of white, calcium carbonate rich material (\%TC values sometimes $>50 \%$ ) alternating with gray or brown material typical of the rest of the core.

\section{DISCUSSION \\ ZACA LAKE POLLEN PRESERVATION}

Large fluctuations in percentages of Asteraceae, Platanus, and indeterminate pollen, as well as total pollen concentration suggest that pollen preservation related to dry and wet phases play a major role in the pollen record. Indeterminate pollen grains in the Zaca Lake sediments have corroded and degraded surfaces (Figures 7A,B), suggesting that the deterioration of pollen grains was primarily caused by chemical weathering. Degraded surfaces on pollen grains have been interpreted as evidence of low water levels in lacustrine environments, even without complete site desiccation. Lowe (1982) found that lake level regressions exposed littoral lake sediments leading to reworking and degradation of pollen grains. Delcourt and Delcourt (1980) found that lower water levels led to increased oxidation of sediments, the primary cause of pollen degradation (Cushing, 1967). Core Z-1C was taken in $12 \mathrm{~m}$ of water and seismic reflection data indicate a continuous package of sediment with no evidence for truncated 


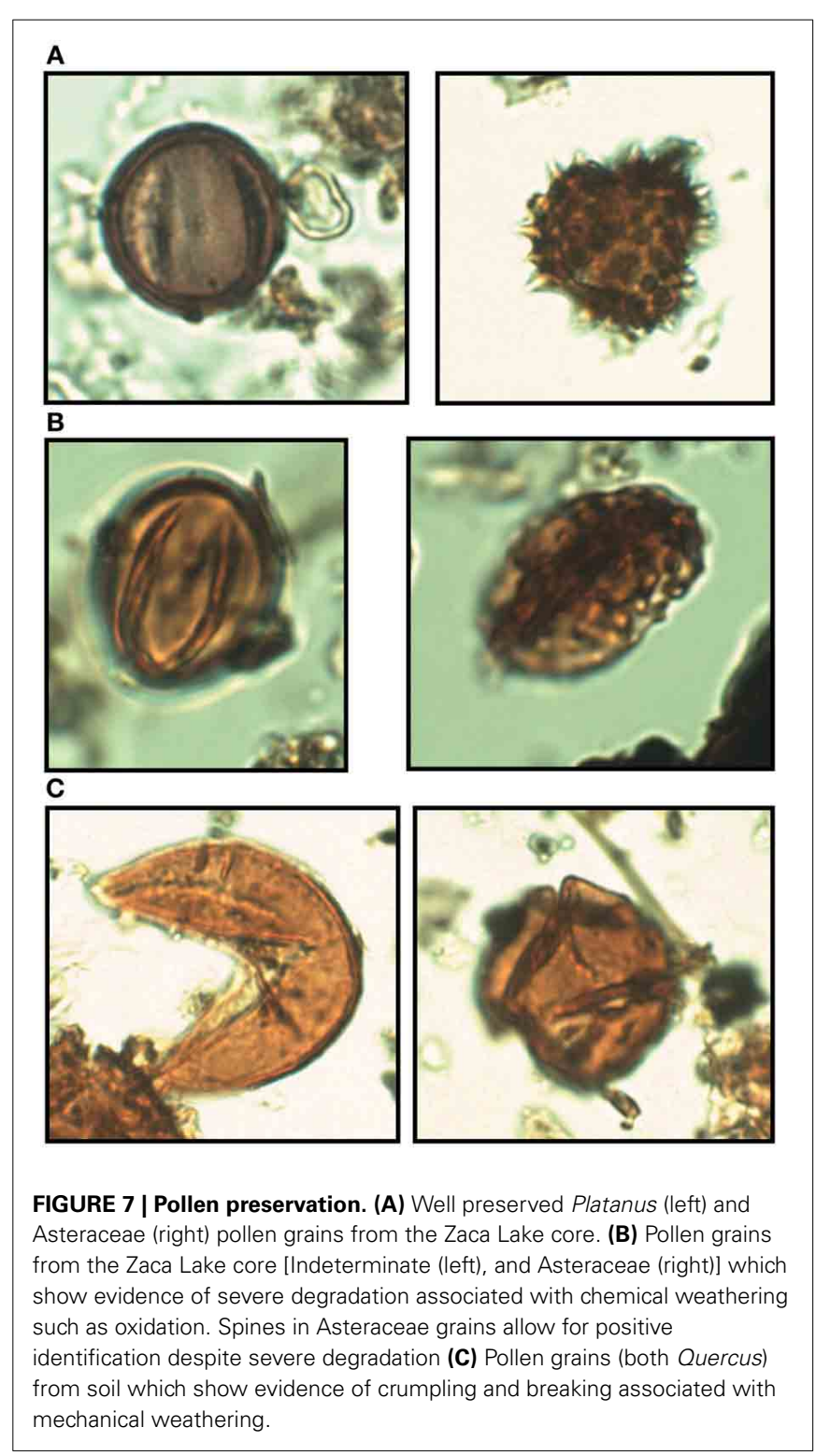

strata that could represent complete desiccation of the lake. In addition we found no sedimentary evidence of desiccation (e.g., mud cracks) therefore we conclude that degradation is not the result of direct, in situ exposure to the atmosphere. However, it is possible that a decrease in water levels could have resulted in a reworking of exposed lake sediments on the lake margins, contributing degraded material to the depocenter. Lower lake levels might also allow for more effective mixing, potentially increasing the oxygenation of lake water at depth.

An alternative explanation of the source of poor pollen preservation is soil in-wash. Pollen initially deposited in soil is often poorly preserved, and increased soil in-wash has been identified as a source of poorly preserved pollen in sediment records (Tipping, 1995; Wilmshurst and McGlone, 2005; Tweddle and Edwards, 2010). However, analysis of modern pollen samples from the soil surrounding the lake indicated that the deteriorated pollen grains found in the soil were crumpled or broken
(Figure 7C), whereas most deteriorated pollen found in the core show signs of degradation (Figures 7A,B). This suggests that the soil around Zaca Lake is unlikely to be a significant source of indeterminate grains found in the $\mathrm{Z1C}$ record, and periods of poor pollen preservation in the Zaca Lake record were more likely a result of lower lake levels than increased soil in-wash.

At Zaca Lake the pollen assemblage in poorly preserved sections is characterized by high percentages of Asteraceae, a decrease in the amount of Platanus, and low overall pollen concentration. This is not unexpected given the effects of poor preservation. Platanus is a grain with a very fine texture and a thin exine that is easily degraded, while Asteraceae is amongst the grains most resistant to destruction and easily identified even if moderately degraded (Havinga, 1984).

The lack of high percentages of Pinus in sections with poorly preserved pollen is unexpected, as Pinus is also resistant to degradation and easily identified. This indicates that poor pollen preservation may not be the sole cause of the pollen assemblage found in these sections, and that there may also be changes in plant cover. The high Asteraceae and low Pinus and Platanus percentages found in poorly preserved sections may be partially a result of a shift from tree species to more drought tolerant annuals during periods of decreased moisture. Other pollen studies in the region from more arid locations have found high Asteraceae percentages even in sediments with well-preserved pollen (Davis, 1992; Cole and Liu, 1994), suggesting that a shift to more Asteraceae at Zaca could also indicate increased aridity.

\section{VEGETATION RECONSTRUCTION AND CLIMATE INTERPRETATION The late holocene dry period (2700 to $2000 \mathrm{cal}$ yr BP)}

Terrestrial climatic conditions in coastal Southern California prior to $\sim 1000 \mathrm{BP}$ are not well documented. Most of what is known comes from marine sources, and the relationship between terrestrial and marine records are sometimes difficult to interpret (Kennett et al., 2007). At Zaca Lake the period between 2700 and $2000 \mathrm{cal}$ yr BP (Zone 4) is dominated by pollen from herbaceous taxa and poorly preserved pollen (Figure 8), with very low abundances of pollen from riparian and tree taxa resulting from reduced tree cover and increased drought-tolerant annuals. We interpret this as a signal of extended dry climate.

Several studies in Southern California indicate that the period between 3000 and 2000 cal yr BP was characterized by dry conditions. Kirby et al. (2012) interpreted high TC and low TOM and $\mathrm{C}: \mathrm{N}$ ratios at Lower Bear Lake during this period to indicate dry conditions (Figure 9). Kirby et al. (2004) recorded high $\delta^{18} \mathrm{O}_{\text {(calcite) }}$ values and low magnetic susceptibility between 3000 and $2000 \mathrm{cal}$ yr BP from a littoral sediment core taken at Lake Elsinore; these proxies were interpreted to reflect more evaporative conditions with less run-off. Using a core from the depocenter of Lake Elsinore, Kirby et al. (2010) found generally low \% sand between 3200 and 2000, indicating lower stream runoff and drier conditions. Outside of Southern California multiple sites representing a variety of paleoclimate proxy indicators (i.e., lake transgression/regression, pollen, tree rings, geomorphology, submerged stumps) identify this as a drought period throughout the central and southern Great Basin (Mensing et al., 2013). Mensing et al. (2013) termed this period the "Late Holocene Dry Period." 


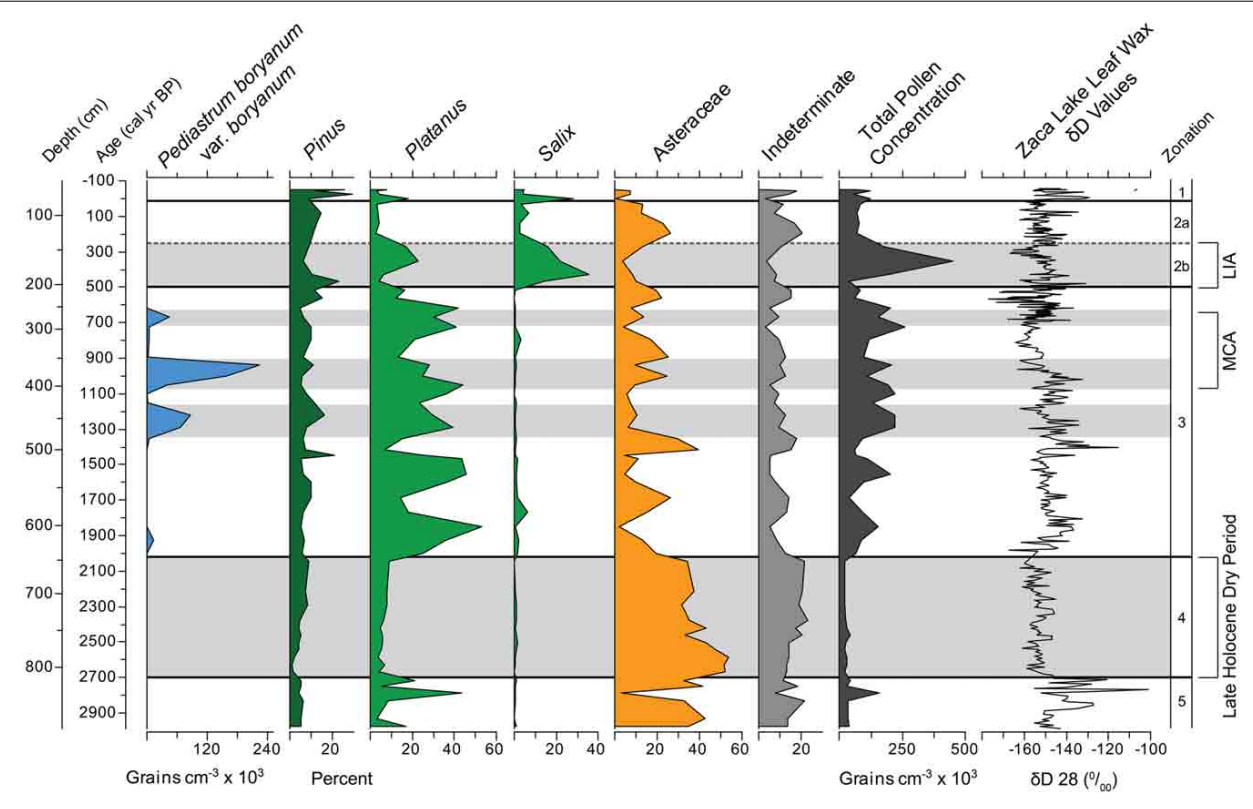

FIGURE 8 | Zaca Lake multi-proxy summary diagram. Leaf wax $\delta \mathrm{D}$ from Feakins et al. (2014). Gray shading represents periods with identified climate signals discussed in the text. 2700-2000 cal yr BP Late Holocene Dry Period identified in the Great Basin and Southern California, Medieval Climate Anomaly, and Little Ice Age identified in numerous records throughout California.
This period also stands out in marine records from SBB. In particular, several records see a substantial shift in conditions at $2000 \mathrm{cal}$ yr BP. Radiolarian assemblages off the west coast of California indicate that the period between 2600-2000 cal yr BP represented a period of increased cool water species, which are interpreted as a shift to drier climate (Pisias, 1978). A shift in circulation was identified by a reduction in bioturbation and a greater ${ }^{14} \mathrm{C}$ reservoir effect after $2000 \mathrm{cal}$ yr BP (Roark et al., 2003). Barron et al. (2010) also found a shift in conditions at 2000 cal yr BP, to an increased percentage of cold water diatoms, the opposite signal as the one found by Pisias (1978). Foraminifera assemblages shifted at $2000 \mathrm{cal} \mathrm{yr} \mathrm{BP}$ from taxa found throughout most of the middle Holocene to taxa found during the Younger Dryas (Fisler and Hendy, 2008). SST suggests average conditions during the 3000-2000 year period and cool temperatures during most of the last 2000 years. Although there is disagreement in the interpretation of marine records as to conditions during the period between 3000-2000 cal yr BP, each record shows a clear shift at $2000 \mathrm{cal}$ yr BP.

\section{The medieval climate anomaly (1050 to $600 \mathrm{cal}$ yr BP)}

Twothousand to fivehundred cal yr BP (Zone 3) is characterized by variation in pollen preservation. Samples with well-preserved pollen and a high percentage of Platanus pollen represent a deep lake with a healthy riparian zone and minimal oxidation of lake sediments. A key difference compared to the preceding 700 years is greater Pinus concentration and Quercus percentages, even in periods of poor pollen preservation, indicating increased forest cover. Additionally, higher overall pollen concentration in poorly preserved samples indicate lake levels may not have been as low during dry periods as before $2000 \mathrm{cal}$ yr BP. Overall, the evidence suggests variable conditions after $2000 \mathrm{cal}$ yr BP with a shift to increased moisture.

Substantial effort has been made in the southwestern United States to understand climate during the Medieval Climate Anomaly (MCA) between approximately 1050 and $600 \mathrm{cal} \mathrm{yr} \mathrm{BP.}$ Tree stumps rooted in modern day Sierra Nevada lakes and rivers have been interpreted as evidence for one or two century-long droughts between $\sim 1050$ and $850 \mathrm{cal} \mathrm{yr} \mathrm{BP}$ and then 700 and 600 cal yr BP (Stine, 1994; Kleppe et al., 2011; Morgan and Pomerleau, 2012). High concentrations of the colonial algae Pediastrum boryanum var. boryanum at Zaca Lake between 1070 and 900 and 700 and $650 \mathrm{cal} \mathrm{yr} \mathrm{BP}$ closely correspond to these periods of inferred droughts, although there are no distinct changes in terrestrial plants.

We interpret the appearance of Pediastrum as a period of increased temperature, although not significant drought, during the MCA. The ecology of Pediastrum boryanum var. boryanum is associated with periods of increased temperature (Jankovska and Komarek, 2000). Several tree ring reconstructions with records from the period indicate increased temperature in the Sierra Nevada Range (Graumlich, 1993; Scuderi, 1993). Additionally, trees dating from 1150 to $600 \mathrm{yr} \mathrm{BP}$ were growing above modern tree line in the eastern Sierra Nevada suggesting warmer than modern temperatures (Millar et al., 2006).

It is somewhat unclear to what extent the MCA droughts found in the Sierra Nevada Range affected the California coast. Many studies from coastal California, have not found a clear MCA drought signal (Davis, 1992; Cole and Liu, 1994; Kirby et al., 2010; Anderson et al., 2013; Cowart and Byrne, 2013), although insufficient temporal resolution in some of these records may limit the ability to identify changes across such a short time span. There 


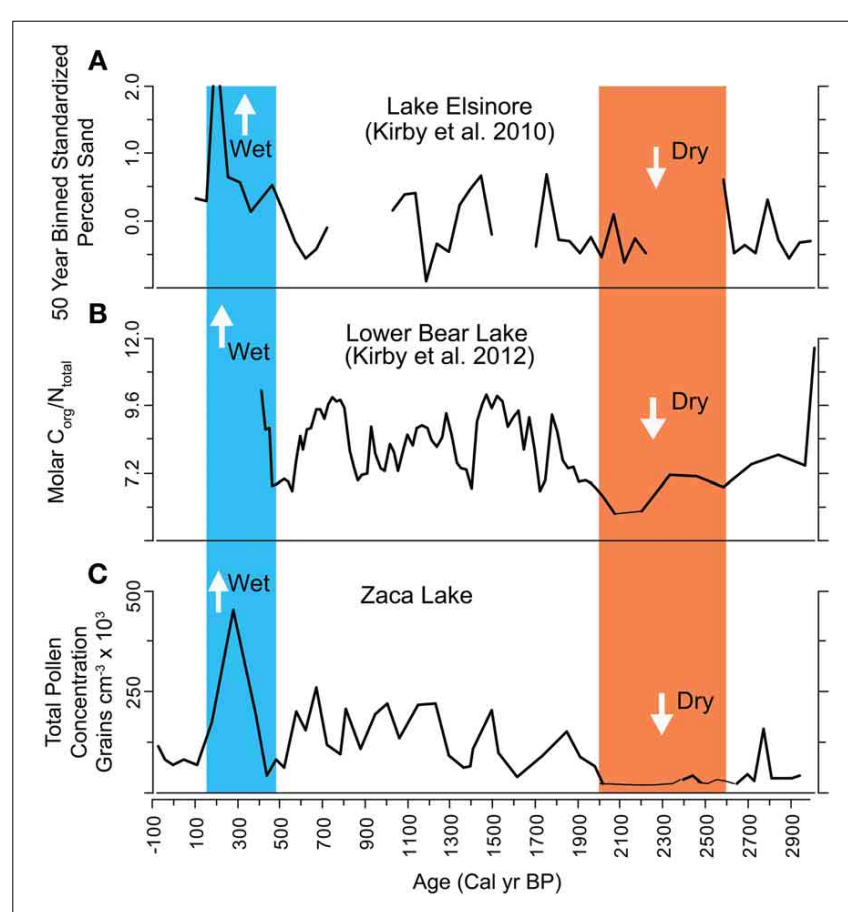

FIGURE 9 | Comparison between Zaca Lake and two other records from Southern California. Red band represents 2700-2000 cal yr BP dry period identified in the Zaca Lake record. Blue band represents Little Ice Age wet period. Data include (A) 50 year binned standardized \% sand from Lake Elsinore (Kirby et al., 2010). High sand values indicate periods of increased runoff. (B) Molar C/N from Lower Bear Lake (Kirby et al., 2012). Higher values indicate periods of increased runoff and elevated lake levels. (C) Overall pollen concentration from Zaca Lake (this study).

does not appear to be any strong signal of drought in the Zaca pollen record.

There is debate as to the SST conditions between 1200 and 800 cal yr BP in the SBB. High $\delta^{18} \mathrm{O}$ values in Globigerina bulloides from 1450 to $600 \mathrm{cal} \mathrm{yr} \mathrm{BP}$ are interpreted as indicative of cool SST (Kennett and Kennett, 2000), as are high percentages of cold water diatoms from 1150 to $550 \mathrm{cal} \mathrm{yr} \mathrm{BP} \mathrm{(Barron} \mathrm{et} \mathrm{al.,} \mathrm{2010).}$ However, the period between 1000-800 cal yr BP was identified as being characterized by warm water species of radiolarian (Pisias, 1978), and between 1150 and $550 \mathrm{cal} \mathrm{yr} \mathrm{BP} \mathrm{higher} \mathrm{percentages} \mathrm{of}$ warm adapted Neogloboquadrina incompta and low percentages of cool adapted $N$. pachyderma were found in a foram record (Fisler and Hendy, 2008).

\section{The little ice age (500 to $250 \mathrm{cal}$ yr BP)}

From 500 to $250 \mathrm{cal} \mathrm{yr} \mathrm{BP} \mathrm{(Zone} 2 \mathrm{~b}$ ) the pollen is characterized by the highest percentages of Salix pollen found in the record, which was likely a result of very high lake levels and possibly consistent stream flow. There is a wide, gently sloping alluvial bench extending several $100 \mathrm{~m}$ from the east shore only a few meters above modern lake level, and rising lake levels may have created saturated soils ideal for Salix colonization. Additionally, high percentages of Platanus, a riparian species, and high total pollen concentration with well-preserved pollen support the argument for higher lake levels. Above average levels of Pinus and Quercus pollen, and low levels of pollen from herbaceous species such as Asteraceae suggest that tree cover was higher than during any other period prior to the last 100 years. The apparent increase in lake levels and tree species suggests that this was the wettest period in the last 3000 years.

Evidence from a wide range of sources in Southern California suggests that the period from about 500 to $200 \mathrm{cal} \mathrm{yr} \mathrm{BP,} \mathrm{often}$ referred to as The Little Ice Age (LIA) was wet and cool. A precipitation reconstruction from the nearby Transverse Ranges using tree rings of big-cone spruce (Pseudotsuga macrophylla) identified 400 to $250 \mathrm{yrs}$ BP as a period of high annual precipitation (Haston and Michaelsen, 1994). The period from 600 to $200 \mathrm{cal}$ yr BP corresponds with high percentages of sand resulting from increased runoff at Lake Elsinore (Kirby et al., 2012). A period of abundant Salix between 400 and 175 cal yr BP in a pollen record from Wawona Meadow, Yosemite National Park, is interpreted as a LIA signal of increased moisture (Anderson and Stillick, 2013).

\section{The modern period (1900 to 2009 AD)}

The most recent 100 years in the record (top part of Zone $2 \mathrm{a}$ and Zone 1) show extreme variability as a result of modern human modification of the landscape. Historical accounts suggest that most of California's oak woodlands were not substantially affected until the American period beginning around $1850 \mathrm{AD}$ (100 cal yr BP) (Mensing, 2006). This appears to be true at Zaca Lake, where the pollen begins substantially showing the impacts of large scale modification starting about 1900 AD. During the modern period there is a sharp increase in Artemisia, as well as very high percentages of Pinus, a result of a combination of organized planting by the forest service around $1900 \mathrm{AD}$ and fire suppression over the past 100 years (Mensing, 1998). The introduction of exotic species to the region by the Spanish in the mid-18th century is an important aspect of the vegetation history of the coast ranges of California. Mensing and Byrne (1998) demonstrated that the invasive Mediterranean annual Erodium cicutarium reached Santa Barbara by $1750 \mathrm{AD}$. In the 20th Century a number of exotic trees were planted around the site, including Eucalyptus (Norris and Norris, 1994), and Cedrus deodara and their pollen have been found in the record (Mensing, 1998).

\section{POTENTIAL CLIMATE DYNAMICS BETWEEN $\mathbf{3 0 0 0}$ AND $2000 \mathrm{cal} \mathrm{yr} \mathrm{BP}$}

Mensing et al. (2013) mapped paleoclimatic reconstructions from multiple proxies (lake levels, pollen, geomorphology) across the Great Basin of Western North America for the period between 2800 and 1800 cal yr BP in relation to the dipole pattern of wet vs. dry regions (Figure 10) identified by Wise (2010). Wise (2010) noted a narrow boundary separated the dry southwest from the wet northwest, the ENSO dipole pattern, roughly corresponding to $40^{\circ} \mathrm{N}$ latitude (Figure 10). A persistent dry southwest was associated with ocean-atmosphere conditions typical of a La Niña-like state, characterized by cool SSTs in the eastern Pacific.

The Zaca Lake record also indicates persistent drought between 2700 and $2000 \mathrm{cal}$ yr BP and maps onto the dry southwest region (Figure 10) In addition, two other sites in Southern California, Lake Elsinore and Little Bear Lake (Kirby et al., 2010, 2012), indicate drought during this period (Figures 9, 10). This suggests that if persistent La-Niña like conditions were 


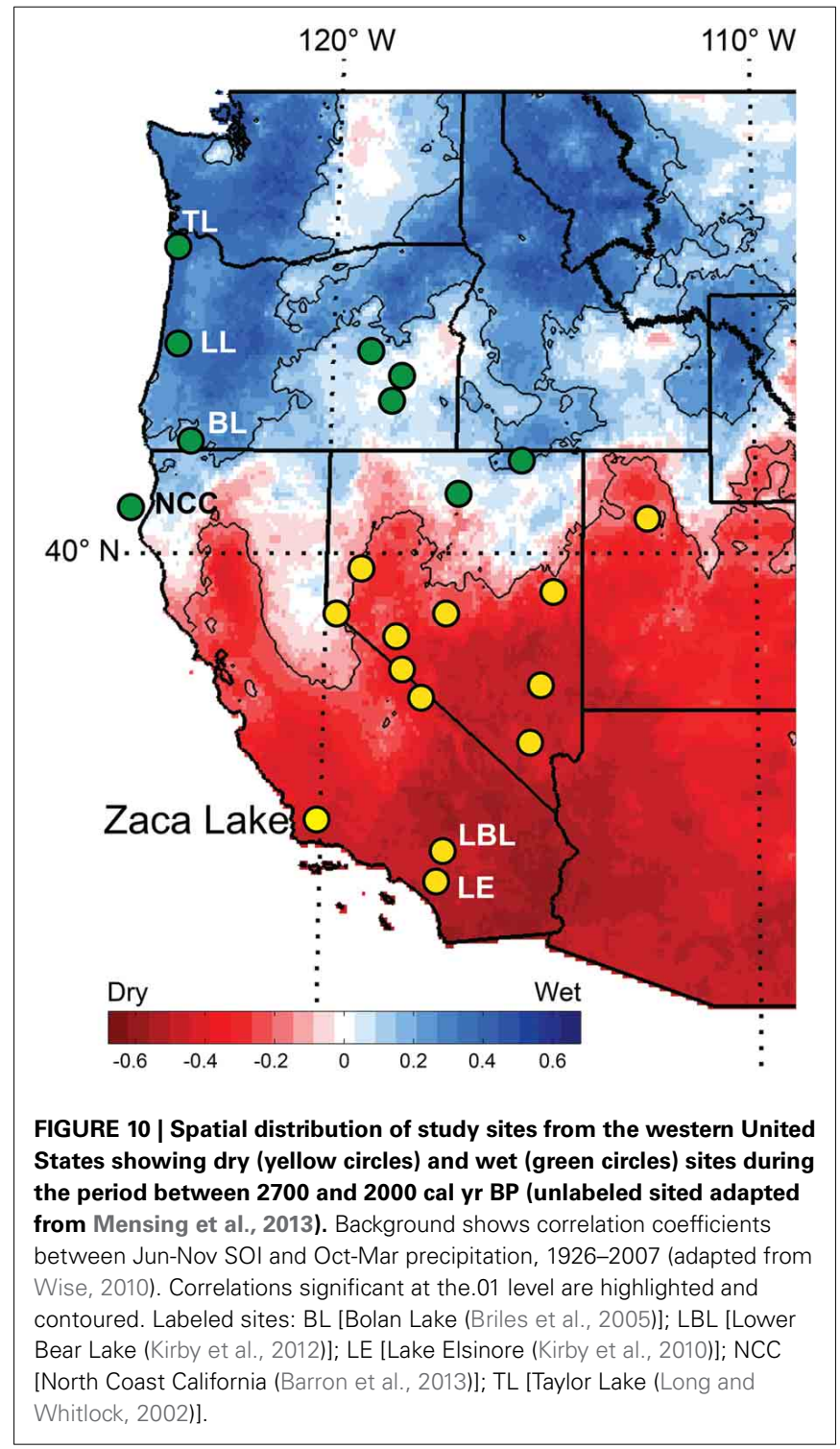

responsible for creating an extended dry period in the late Holocene, this pattern extended at least from Southern California through the central Great Basin.

North of the ENSO dipole boundary in western North America periods of less frequent El Niño would likely result in increased precipitation, and sites would be expected to indicate wet conditions. Off of the coast of northern California wet conditions persisted between 3000 and 2000 (Barron et al., 2013). They interpret higher levels of Alnus and Quercus pollen during this period as indicative of increased river runoff associated with increased winter precipitation. Charcoal and pollen from Bolan Lake, Oregon were used to reconstruct fire and climate history, and high levels of Abies and low fire frequency between 4500 and $2100 \mathrm{cal} \mathrm{yr} \mathrm{BP}$ were interpreted as indicative of the wettest period in the Holocene (Briles et al., 2005). Fire and vegetation histories in Oregon from Little Lake (Long et al., 1998) and Taylor Lake (Long and Whitlock, 2002) both found a shift to reduced fire frequency beginning around $2700 \mathrm{cal} \mathrm{yr} \mathrm{BP,} \mathrm{which}$ they interpreted as wetter climate. The evidence from these sites suggest conditions generally wet climate from 3000 to $2000 \mathrm{cal}$ yr BP north of the $40^{\circ} \mathrm{N}$ dipole, supporting the hypothesis of Mensing et al. (2013).

Additional evidence from South America also suggests that the period was characterized by low El Niño frequency. Sediment changes in a core from the Andes were interpreted to record changes in the frequency of ENSO events, and the period between 2500 and 1800 cal yr BP was identified as a period of low El Niño frequency (Moy et al., 2002). Percent sand in a lake on the Galapagos Islands increased just before $2000 \mathrm{cal}$ yr BP, indicating an increase in the strength and frequency of El Niño events beginning at that time (Conroy et al., 2008). Finally, an abrupt shift to more frequent El Niño events at about $2000 \mathrm{cal}$ yr BP was identified using a variety of geochemical proxies from a core taken off of the Peruvian coast (Makou et al., 2010).

Overall, climate records from western North America show a period of persistent dry climate between $\sim 2700$ and 2000 cal yr BP that is potentially associated with La Niña-type ocean/atmosphere circulation patterns. Drought persisted in the central and southern Great Basin and along the Southern California coast and wetter than modern climate was typical north of $40^{\circ} \mathrm{N}$. Additionally, evidence for western South America suggests that this period was indeed characterized by reduced $\mathrm{El}$ Nino frequency (Moy et al., 2002; Conroy et al., 2008; Makou et al., 2010).

\section{POLLEN INFORMED LEAF WAX D/H INTERPRETATIONS}

Plant leaf wax D/H data can be paired with pollen data to potentially infer changes in moisture source region through time and hypothesize ocean/atmosphere dynamics associated with shifts in climate. While plant leaf waxes represent valued biomarkers for terrestrial vegetation, they are not source specific and derive from most of the plants in the catchment with the exception of Pinus which do not produce the long chain $\mathrm{C}_{28} n$-alkanoic acid. Pollen evidence for plant type change has been proposed as a means to separate isotopic effects from species change and hydrological change in sedimentary leaf wax D/H (Feakins, 2013). We acknowledge that pollen and leaf wax have: (1) different functions for the plant; (2) varied patterns of pollen and leaf wax production between species, and (3) the mechanisms of pollen release are not the same as ablation of wax from a leaf. Nevertheless, pollen represents the best means to untangle changing vegetation contributions to non-species specific plant leaf wax biomarkers (Feakins et al., 2013). Variations in the $\mathrm{D} / \mathrm{H}$ fractionation between source water and plant leaf waxes have been observed in different plant types (Sachse et al., 2012) and thus the changing proportions of plant taxa, revealed by pollen, can provide a useful guide to where ecological changes may influence the $\mathrm{D} / \mathrm{H}$ record.

Evaporatively D-enriched surface soil water is not a significant source of moisture for the dominant woody plant types in Southern California (Feakins and Sessions, 2010) and the Zaca Lake catchment. Where plant type changes can be ruled out as a source of $\mathrm{D} / \mathrm{H}$ variations, we interpret leaf wax $\mathrm{D} / \mathrm{H}$ as a proxy for precipitation $\mathrm{D} / \mathrm{H}$.

Comparing the pollen and leaf wax $\mathrm{D} / \mathrm{H}$ reconstructions from $\mathrm{Z}-1 \mathrm{C}$ (Figure 8) it is clear that the pollen changes in Zone 5 are 
abrupt and accompanied by large swings in plant leaf wax $\mathrm{D} / \mathrm{H}$. We suspect that abrupt input changes, particularly in the relative abundances of Platanus and Asteraceae pollen, may also modulate the leaf wax inputs and $\delta \mathrm{D}_{\text {wax }}$ values. We suggest that the leaf wax $\mathrm{D} / \mathrm{H}$ may be less robustly interpreted as a moisture source proxy in Zone 5, and may instead be subject to variable sedimentary inputs. What is clear is that the variability in this interval was the precursor to a many-centuries-long drought that followed.

During the multi-centennial drought (Zone 4), when pollen inputs are stable the similarly stable $\delta \mathrm{D}$ values of $-160 \%$ most likely indicate moisture source trajectories from the northern $\mathrm{N}$ Pacific. Stable $\delta \mathrm{D}_{\text {wax }}$ values could alternatively be achieved by reworking and mixing of leaf waxes as described for the discussion of indeterminate pollen grains, however, we see no signs of modification of molecular abundance distributions in the core, suggesting that leaf wax biomarkers have not been subject to post-depositional diagenesis (Feakins et al., 2014). To reconstruct the $\delta \mathrm{D}$ values of paleoprecipitation during this multi-centennial drought (Zone 4), we can apply a reasonable apparent fractionation. Quercus is a fairly stable pollen contributor of $\sim 20 \%$ throughout Zone 4 with an increase toward $40 \%$ after Zone 4 (Figure 5) and Q. agrifolia is co-dominant in the vegetation assemblage of the catchment today. Based on $\varepsilon_{w a x / w}$ of $-94 \%$ ( 1 compound $\sigma=22 \%, n=10$ ) for Q. agrifolia collected within the Zaca catchment (Feakins et al., 2014), we might infer precipitation isotopes during this time interval were around $-73 \%$, which is more depleted than modern precipitation values collected in the catchment averaging ca. $-50 \%$ (Feakins et al., 2014). This fractionation is consistent with the mean value obtained from a multi-species survey across Southern California (Feakins and Sessions, 2010, GCA) as well as fractionations inferred from leaf waxes sampled from marine sediments of the SBB (Li et al., 2009, 2011), as discussed in Feakins et al. (2014). Storm track studies reveal that low $\delta \mathrm{D}$ values suggest a more northerly Pacific moisture source than today (Friedman et al., 2002; McCabe-Glynn et al., 2013). However, we have not determined the fractionations of all species in the catchment and this leads to uncertainty in the average fractionation of sedimentary leaf waxes, when vegetation changes occur in the catchment. Although pollen proportions do not linearly translate to either community proportions or leaf wax production, we note that the variability of Asteraceae pollen \% may induce a bias during dry intervals if this also corresponds to an increase in its leaf wax contribution to the core and it the fractionation of this species is significantly different to the value for Q. agrifolia. Ideally $\varepsilon_{w a x / w}$ would be determined for the Asteraceae ( $40 \%$ of the pollen in this interval) to better predict absolute $\delta \mathrm{D}_{\text {water }}$ values. Asteraceae are an aridity indicator taxon (which often corresponds to high $\delta \mathrm{D}$ values in many intervals of the core). However, in this interval, high Asteraceae counts are associated with low $\delta \mathrm{D}$ values, indicating storm tracks from northerly N Pacific moisture sources during this long drought. The paired pollen-leaf wax evidence suggests low precipitation totals and a predominantly northerly moisture source, perhaps consistent with a persistent La Niña-like state in the tropical Pacific.

In contrast, high Asteraceae (low Platanus) proportions at $\sim 1350$ and 1000 cal yr BP align with high $\delta \mathrm{D}$ values centered on 1400 and $1010 \mathrm{cal} \mathrm{yr} \mathrm{BP,} \mathrm{revealing} \mathrm{atmospheric} \mathrm{conditions}$ differing from that of the LHDP in the western United States. High Asteraceae-high $\delta \mathrm{D}_{\text {wax }}$ intervals suggest droughts caused by reduced inputs of moisture from high latitudes.

High $\delta \mathrm{D}_{\text {wax }}$ values are also reported at ca. $1900-1800$ cal yr BP during a period of inferred wet climate with low Asteraceae and high Platanus proportions. This leads to the intriguing implication that atmospheric circulation bringing subtropical moisture with elevated $\delta \mathrm{D}$ values, can lead to either wet or dry conditions in California. In this scenario we would anticipate a large number of subtropical storms, but without the extreme rainout D-depletion seen in some intense storms.

The most D-depleted values are seen after the termination of the multi-centennial drought in 1980-1960 cal yr BP, after the end of the MCA droughts with low $\delta$ D values ca. $620-520 \mathrm{cal}$ yr BP and during the LIA ca. 330-270 cal yr BP. Each of these sets of D-depleted horizons are interpreted as representing wet conditions fed by frequent, intense storms from mid-latitude North Pacific moisture sources (with cold, high condensation elevations and little post-condensation evaporation) or by intense subtropical pineapple express type storms (Coplen et al., 2008). Either of these scenarios would explain D-depleted precipitation isotopes and sufficient precipitation to bring the catchment out of drought and into pluvial conditions.

In Zone 1 , the period of human disturbance and introduced plants, $\delta \mathrm{D}$ values are generally similar to Zone 2 a suggesting minimal modulation of the $\mathrm{D} / \mathrm{H}$ record of moisture sources, despite human interference in the catchment. Although two periods of D-enriched values in the last 100 years indicating dry conditions and/or subtropical Pacific moistures, they do not reach the extremes seen in Zone 3, in either the Asteraceae proportions or $\delta \mathrm{D}_{\text {wax }}$. Neither do we see the D-depleted extremes of the LIA in the Zone 1. The implication is that drought and pluvial conditions of the last 100 years have been more modest than those witnessed in the last 1500 years, and certainly not as persistent as the multi-centennial drought event of 2700 to $2000 \mathrm{cal}$ yrs BP.

\section{CONCLUSION}

We reconstructed a 3000 year record of pollen from Zaca Lake, Southern California. Variations in pollen preservation as well as changes in abundance of major taxa are used to infer climate. We propose that when pollen is more degraded this indicates more diagenetic reworking on the lake margins, prior to deposition in the depocenter, and this would occur primarily when conditions are drier than normal and lake levels are lower. Through this approach we discover a multi-centennial drought from 2700 to $2000 \mathrm{cal}$ yr BP in Southern California. This dry period corresponds closely with a similar dry period identified by Mensing et al. (2013) in the central and southern Great Basin. We suggest that the drought found at Zaca confirms that this dry period extended at least from coastal Southern California into the central Great Basin of western North America. Paired pollen-leaf wax data suggest a predominantly northerly moisture source for this multi-centennial drought, however, we infer from the pollen that on average, the number of storms reaching the site must have been reduced. Additionally, we suggest that an extended period of La Niña-type ocean/atmospheric circulation and low El Niño 
frequency may have been a key climate diver. Evidence from the west coast of South America indicates a period of reduced El Niño activity during this period. The spatial distribution of wet and dry signals from sites in North America follows the dipole described by Wise (2010) for the response of climate to La Niña.

Evidence during the period of the Medieval Climate Anomaly suggests that temperatures were warmer than modern, but that this was not a period of extreme drought along southern coastal California. The period corresponding to the LIA indicates wetter than modern climate and likely the wettest period during the last 3000 years in this region. In the last century, human impacts are noticeable through the appearance of exotic species from the Mediterranean, and increased forest cover associated with reforestation efforts and fire suppression.

The paired pollen/leaf wax data correspond at certain points in time, providing an opportunity to hypothesize the predominant moisture source for multi-decadal droughts and wet periods. This relationship needs to be explored further.

\section{AUTHOR CONTRIBUTIONS}

Theodore Dingemans counted the pollen and Theodore Dingemans and Scott A. Mensing wrote the paper. Sarah J. Feakins and Matthew E. Kirby proposed the paleoclimate study of Zaca Lake, collected the cores, shared the samples and geochemical data and discussed interpretations. Matthew E. Kirby picked the macroscopic organic fragments and Susan R. H. Zimmerman provided radiocarbon dates. All authors reviewed and edited the manuscript.

\section{ACKNOWLEDGMENTS}

The research was supported by US National Science Foundation Grant EAR-1002656 to Sarah J. Feakins and Matthew E. Kirby; coring was supported by startup funding from the University of Southern California to Sarah J. Feakins; radiocarbon dating was supported by Lawrence Livermore National Laboratory grant LDRD-09ERI003 to Susan R. H. Zimmerman. We thank the Zaca Lake Foundation for access to the lake. This article is LLNL-JRNL-652277.

\section{REFERENCES}

Anderson, R. S., and Byrd, B. F. (1998). Late-Holocene vegetation changes from the Las Flores Creek coastal lowlands, San Diego County, California. Madroño 45, 171-182.

Anderson, R. S., Ejarque, A., Brown, P. M., and Hallett, D. J. (2013). Holocene and historical vegetation change and fire history on the north-central coast of California, USA. Holocene 23, 1797-1810. doi: 10.1177/0959683613505344

Anderson, R. S., and Stillick, R. D. (2013). 800 years of vegetation change, fire and human settlement in the Sierra Nevada of California, USA. Holocene 23, 823-832. doi: 10.1177/0959683612471985

Barron, J. A., Bukry, D., and Field, D. (2010). Santa Barbara Basin diatom and silicoflagellate response to global climate anomalies during the past 2200 years. Quatern. Int. 215, 34-44. doi: 10.1016/j.quaint.2008.08.007

Barron, J. A., Heusser, L. E., Addison, J. A., Bukry, D., Kusler, J. E., and Finney, B. (2013). High-resolution paleoclimatology of the coastal margin of northernmost California during the past 7,400 years. San Francisco, CA: PP33A-1902, poster, Fall AGU.

Behl, R. J. (1999). Since Bramlette (1946): the Miocene Monterey Formation of California revisited. Geol. Soc. Am. Spec. Paper 338, 301-313. doi: 10.1130/08137-2338-8.301

Birks, B. (1970). Inwashed Pollen Spectra at Loch Fada, Isle of Skye. New Phytol. 69, 807-820. doi: 10.1111/j.1469-8137.1970.tb02464.x
Blaauw, M., and Christen, J. A. (2011). Flexible paleoclimate age-depth models using an autoregressive gamma process. Bayesian Anal. 6, 457-474. doi: 10.1214/11-BA618

Briles, C. E., Whitlock, C., and Bartlein, P. J. (2005). Postglacial vegetation, fire, and climate history of the Siskiyou Mountains, Oregon, USA. Quatern. Res. 64, 44-56. doi: 10.1016/j.yqres.2005.03.001

Buenning, N. H., Stott, L., Kanner, L., and Yoshimura, K. (2013). Diagnosing Atmospheric influences on the Interannual ${ }^{18} \mathrm{O} /{ }^{16} \mathrm{O}$ variations in Western U.S. Precipitation. Water 5, 1116-1140. doi: 10.3390/w5031116

Byrne, R., Ingram, B. L., Starratt, S., Malamud-Roam, F., Collins, J. N., and Conrad, M. E. (2001). Carbon-Isotope, Diatom, and Pollen Evidence for Late Holocene Salinity Change in a Brackish Marsh in the San Francisco Estuary. Quatern. Res. 55, 66-76. doi: 10.1006/qres.2000.2199

Campbell, I. D. (1999). Quaternary pollen taphonomy: examples of differential redeposition and differential preservation. Palaeogeogr. Palaeoclimatol. Palaeoecol. 149, 245-256. doi: 10.1080/01916122.1991.9989387

Caponigro, M. A. (1976). The Diatom Stratigraphy and Paleolimnology of Zaca Lake, California. Unpublished M.A. thesis, University of California, Santa Barbara.

Cayan, D. R., and Rhoads, J. (1984). Local relationships between United States west coast precipitation and monthly mean circulation parameters. Mon. Weather Rev. 112, 1276-1282.

Cole, K. L., and Liu, G. W. (1994). Holocene Paleoecology of an Estuary on Santa Rosa Island, California. Quatern. Res. 41, 326-335. doi: 10.1006/qres. 1994.1037

Cole, K. L., and Wahl, E. (2000). A Late Holocene Paleoecological Record from Torrey Pines State Reserve, California. Quatern. Res. 53, 341-351. doi: 10.1006/qres.1999.2121

Conroy, J. L., Overpeck, J. T., Cole, J. E., Shanahan, T. M., and Steinitz-Kannan, M. (2008). Holocene changes in eastern tropical Pacific climate inferred from a Galápagos lake sediment record. Quatern. Sci. Rev. 27, 1166-1180. doi: 10.1016/j.quascirev.2008.02.015

Cook, E. R., Woodhouse, C. A., Eakin, M., Meko, D. M., and Stahle, D. W. (2004). Long-Term aridity changes in the Western United States. Science 306, 1015-1018. doi: 10.1126/science.1102586

Coplen, T. B., Neiman, P. J., White, A. B., Landwehr, J. M., Ralph, F. M., and Dettinger, M. D. (2008). Extreme changes in stable hydrogen isotopes and precipitation characteristics in a landfalling Pacific storm. Geophys. Res. Lett. 35, L21808. doi: 10.1029/2008GL035481

Cowart, A., and Byrne, R. (2013). A paleolimnological record of late holocene vegetation change from the Central California Coast. California Archaeol. 5, 337-352. doi: 10.1179/1947461X13Z.00000000018

Cushing, E. J. (1967). Evidence for differential pollen preservation in late quaternary sediments in Minnesota. Rev. Palaeobot. Palynol. 4, 87-101. doi: 10.1016/0034-6667(67)90175-3

Daly, C., Halbleib, M., Smith, J. I., Gibson, W. P., Doggett, M. K., Taylor, G. H., et al. (2008). Physiographically sensitive mapping of climatological temperature and precipitation across the conterminous United States. Int. J. Climatol. 28, 2031-2064. doi: 10.1002/joc.1688

Davis, O. K. (1992). Rapid climatic change in coastal southern California inferred from pollen analysis of San Joaquin Marsh. Quatern. Res. 37, 89-100. doi: 10.1016/0033-5894(92)90008-7

Dean, W. E. (1974). Determination of carbonate and organic matter in calcareous sediments by loss on ignition comparison to other methods. J. Sediment Petrol. 44, 242-248.

Delcourt, P. A., and Delcourt, H. R. (1980). Pollen preservation and quaternary environmental history in the Southeastern United States. Palynology 4, 215-231. doi: 10.1080/01916122.1980.9989209

Dettinger, M. D. (2011). Climate change, atmospheric rivers and floods in California-A multimodel analysis of storm frequency and magnitude changes. J. Am. Water Res. Assoc. 47, 514-523. doi: 10.1111/j.1752-1688.2011.00546.x

Faegri, K., and Iversen, J. (1985). Textbook of Pollen Analysis. 4th Edn. New York, NY: Hafner Press.

Feakins, S. J. (2013). Pollen-corrected leaf wax D/H reconstructions of northeast African hydrological changes during the lake Miocene. Palaeogeogr. Palaeoclimatol. Palaeoecol. 374, 62-71. doi: 10.1016/j.palaeo.2013.01.004

Feakins, S. J., Kirby, M. E., Cheetham, M. I., Ibarra, Y., and Zimmerman, S. R. H. (2014). Fluctuation in leaf wax D/H ratio from a southern California lake records significant variability in isotopes in precipitation during the late Holocene. Organ. Geochem. 66, 48-59. doi: 10.1016/j.orggeochem.2013.10.015 
Feakins, S. J., Levin, N. E., Liddy, H. M., Sieracki, A., Eglinton, T. I., and Bonnefille, R. (2013). Northeast African vegetation change over 12 m.y. Geology 41, 295-298. doi: 10.1130/G33845.1

Feakins, S. J., and Sessions, A. L. (2010). Controls on the D/H ratios of plant leaf wax in an arid ecosystem. Geochim. Cosmochim. Acta 74, 2128-2141. doi: 10.1016/j.gca.2010.01.016

Field, B., and Baumgartner, T. R. (2000). A 900 year stable isotope record of interdecadal and centennial change from the California Current. Paleoceanography 15, 695-708. doi: 10.1029/1999PA000480

Fisler, J., and Hendy, I. L. (2008). California current system response to late holocene climate cooling in Southern California. Geophys. Res. Lett. 35, 1-5. doi: 10.1029/2008GL033902

Friedman, I., Harris, J. M., Smith, G. I., and Johnson, C. A. (2002). Stable isotope composition of waters in the Great Basin, United States 1. Air-mass trajectories. J. Geophys. Res. Atmospher. 107, 1-14. doi: 10.1029/2001JD000565

Gat, J. R. (1996). Oxygen and hydrogen isotopes in the hydrologic cycle. Annu. Rev. Earth Planet. Sci. Lett. 24, 225-262. doi: 10.1146/annurev.earth.24. 1.225

Graumlich, L. J. (1993). A 1000-year record of temperature and precipitation in the Sierra Nevada. Quatern. Res. 39, 249-255. doi: 10.1006/qres. 1993.1029

Grelaud, M., Schimmelmann, A., and Beaufort, L. (2009). Coccolithophore response to climate and surface hydrography in Santa Barbara Basin, California, AD 1917-2004. Biogeosciences 6, 2025-2039. doi: 10.5194/bg-6-2025-2009

Hall, C. A. (1981a). Map of geology along the Little Pine Fault, parts of the Sisquoc, Foxen Canyon, Zaca Lake, Bald Mountain, Los Olivos, and Figueroa Mountain quadrangles, Santa Barbara County, California. U.S. Geologic Survey Miscellaneous Field Studies. Map MF-1285.

Hall, S. A. (1981b). Deteriorated Pollen grains and the interpretation of quaternary pollen diagrams. Rev. Palaeobot. Palynol. 32, 193-206. doi: 10.1016/00346667(81)90003-8

Hall, S. A., and Valastro, S. (1995). Grassland vegetation in the southern great plains during the last glacial maximum. Quatern. Res. 44, 237-245. doi: 10.1006/qres.1995.1068

Haston, L., and Michaelsen, J. (1994). Long-term central california precipitation variability and relationships to El Nino-Southern Oscillation. J. Clim. 7, 1373-1387. doi: 10.1175/1520-0442(1994)007\%3C1373:LTCCCP\%3E2.0.CO;2

Havinga, A. J. (1967). Palynology and pollen preservation. Rev. Palaeobot. Palynol. 2, 81-98. doi: 10.1016/0034-6667(67)90138-8

Havinga, A. J. (1984). A 20-year experimental investigation into the differential corrosion susceptibility of pollen and spores in various soil types. Pollen Spores 26 , 541-558.

Heiri, O., Lotter, A. F., and Lemcke, G. (2001). Loss on ignition as a method for estimating organic and carbonate content in sediments: reproducibility and comparability of results. J. Paleolimnol. 25, 101-110. doi: 10.1023/A:1008119611481

Herweijer, C., Seager, R., Cook, E. R., and Emile-Geay, J. (2007). North american droughts of the last millennium from a gridded network of tree-ring data. J. Clim. 20, 1353-1376. doi: 10.1175/JCLI4042.1

Heusser, L. (1978). Pollen in Santa Barbara Basin, California: a 12,000-yr record. Geol. Soc. Am. Bull. 89, 673-678. doi: 10.1130/0016-7606(1978)89<673: PISBBC $>2.0 . \mathrm{CO} ; 2$

Heusser, L. E., and Sirocko, F. (1997). Millennial pulsing of environmental change in southern California from the past 24 k.y.: a record of Indo-Pacific ENSO events? Geology 25, 243-246. doi: 10.1130/0091-7613(1997)025<0243: MPOECI>2.3.CO;2

Huguet, C., Schimmelmann, A., Thunell, R., Lourens, L. J., Damst,é, J. S. S., and Schouten, S. (2007). A study of the TEX 86 paleothermometer in the water column and sediments of the Santa Barbara Basin, California. Paleoceanography 22, 1-9. doi: 10.1029/2006PA001310

Ibarra, Y., Corsetti, F. A., Cheetham, M. I., and Feakins, S. J. (2014). Were fossil spring-associated carbonates near Zaca Lake, Santa Barbara, California deposited under an ambient or thermal regime? Sediment. Geol. 301, 15-25. doi: 10.1016/j.sedgeo.2013.12.005

Jankovska, V., and Komarek, J. (2000). Indicative value of pediastrum and other coccal green algae in palaeoecology. Folia Geobot. 35, 59-82. doi: 10.1007/ BF02803087

Kapp, R. O., Davis, O. K., and King, J. E. (2000). Ronald O. Kapp's Pollen and Spores. 2nd Edn. College Station, TX: American Association of Stratigraphic Palynologists.
Kennett, D. J., and Kennett, J. P. (2000). Competitive and cooperative responses to climatic instability in Coastal Southern California. Am. Antiquity 65, 379-395. doi: 10.2307/2694065

Kennett, D. J., Kennett, J. P., Erlandson, J. M., and Cannariato, K. G. (2007). Human responses to Middle Holocene climate change on California's Channel Islands. Quatern. Sci. Rev. 26, 351-367. doi: 10.1016/j.quascirev.2006.07.019

Kirby, M. E., Lund, S. P., Anderson, M. A., and Bird, B. W. (2007). Insolation forcing of Holocene climate change in Southern California: a sediment study from Lake Elsinore. J. Paleolimnol. 38, 395-417. doi: 10.1007/s10933-006-9085-7

Kirby, M. E., Lund, S. P., Patterson, W. P., Anderson, M. A., Bird, B. W., Ivanovici, L., et al. (2010). A Holocene record of Pacific Decadal Oscillation (PDO)-related hydrologic variability in Southern California (Lake Elsinore, CA). J. Paleolimnol. 44, 819-839. doi: 10.1007/s10933-010-9454-0

Kirby, M. E., Poulsen, C. J., Lund, S. P., Patterson, W. P., Reidy, L., and Hammond, D. E. (2004). Late Holocene lake-level dynamics inferred from magnetic susceptibility and stable oxygen isotope data: Lake Elsinore, Southern California (USA). J. Paleolimnol. 31, 275-293. doi: 10.1023/B:JOPL.0000021710.39800.f6

Kirby, M. E., Zimmerman, S. R. H., Patterson, W. P., and Rivera, J. J. (2012). A 9170-year record of decadal-to-multi-centennial scale pluvial episodes from the coastal Southwest United States: a role for atmospheric rivers? Quatern. Sci. Rev. 46, 57-65. doi: 10.1016/j.quascirev.2012.05.008

Kleppe, J. A., Brothers, D. S., Kent, G. M., Biondi, F., Jensen, S., and Driscoll, N. W. (2011). Duration and severity of medieval drought in the Lake Tahoe Basin. Quatern. Sci. Rev. 30, 3269-3279. doi: 10.1016/j.quascirev.2011.08.015

Lee, J. E., and Fung, I. (2008). Amount effect of water isotopes and quantitative analysis of post-condensation processes. Hydrol. Process. 22, 1-8. doi: 10.1002/hyp.6637

Li, C., Sessions, A. L., Kinnaman, F. S., and Valentine, D. L. (2009). Hydrogenisotopic variability in lipids from Santa Barbara Basin sediments. Geochim. Cosmochim. Acta 73, 4803-4823. doi: 10.1016/j.gca.2009.05.056

Li, C., Sessions, A. L., Valentine, D. L., and Thiagarajan, N. (2011). D/H variation in terrestrial lipids from Santa Barbara Basin over the past 1400years: a preliminary assessment of paleoclimatic relevance. Organic Geochem. 42, 15-24. doi: 10.1016/j.orggeochem.2010.09.011

Long, C. J., and Whitlock, C. (2002). Fire and vegetation history from the coastal rain forest of the Western Oregon Coast Range. Quatern. Res. 58, 215-225. doi: 10.1006/qres.2002.2378

Long, C. J., Whitlock, C., Bartlein, P. J., and Millspaugh, S. H. (1998). A 9000-year fire history from the Oregon Coast Range, based on a high-resolution charcoal study. Can. J. Forest Res. 28, 774-787. doi: 10.1139/cjfr-28-5-774

Lowe, J. (1982). Three pollen profiles from the Teith Valley, Perthshire, Scotland. II. Analysis of Deteriorated Pollen. New Phytol. 90, 371-385. doi: 10.1111/j.14698137.1982.tb03268.x

MacDonald, G. M., Kremenetski, K. V., and Hidalgo, H. G. (2008). Southern California and the perfect drought: simultaneous prolonged drought in southern California and the Sacramento and Colorado River systems. Quatern. Int. 188, 11-23. doi: 10.1016/j.quaint.2007.06.027

Makou, M. C., Eglinton, T. I., Oppo, D. W., and Hughen, K. A. (2010). Postglacial changes in El Niño and La Niña behavior. Geology 38, 43-46. doi: 10.1130/G30366.1

Malamud-Roam, F. P., Ingram, L. B., Hughes, M., and Florsheim, J. L. (2006). Holocene paleoclimate records from a large California estuarine system and its watershed region: linking watershed climate and bay conditions. Quatern. Sci. Rev. 25, 1570-1598. doi: 10.1016/j.quascirev.2005.11.012

McCabe-Glynn, S., Johnson, K. R., Strong, C., Berkelhammer, M., Sinha, A., Cheng, H., et al. (2013). Variable North Pacific influence on drought in southwestern North America since AD 854. Nat. Geosci. 6, 617-621. doi: 10.1038/ngeo1862

Meko, D. M., Therrell, M. D., Baisan, C. H., and Hughes, M. K. (2001). Sacramento river flow reconstructed to A.D. 869 From Tree Rings. J. Am. Water Res. Assoc. 37, 1029-1039. doi: 10.1111/j.1752-1688.2001.tb05530.x

Mensing, S. A. (1993). The Impact of European Settlement on Oak Woodlands and Fire: Pollen and Charcoal Evidence from the Transverse Ranges, California. Unpublished Dissertation, University of California, Berkeley.

Mensing, S. A. (1998). 560 years of vegetation change in the region of Santa Barbara, California. Madroño 45, 1-11.

Mensing, S. A. (2006). The History of Oak Woodlands in California, Part II: the Native American and Historic Period. California Geographer. 46, 1-31.

Mensing, S. A., and Byrne, R. (1998). Pre-Mission Invasion of Erodium cicutarium in California. J. Biogeogr. 25, 757-762. doi: 10.1046/j.1365-2699.1998.2540757.x 
Mensing, S. A., Michaelsen, J., and Byrne, R. (1999). A 560-Year Record of Santa Ana Fires Reconstructed from Charcoal Deposited in the Santa Barbara Basin, California. Quatern. Res. 51, 295-305. doi: 10.1006/qres.1999.2035

Mensing, S. A., Sharpe, S. E., Tunno, I., Sada, D. W., Thomas, J. M., Starratt, S., et al. (2013). The Late Holocene Dry Period: multiproxy evidence for an extended drought between 2800 and $1850 \mathrm{cal}$ yr BP across the central Great Basin, USA. Quatern. Sci. Rev. 78, 266-282. doi: 10.1016/j.quascirev.2013. 08.010

Millar, C. I., King, J. C., Westfall, R. D., Alden, H. A., and Delany, D. L. (2006). Late Holocene forest dynamics, volcanism, and climate change at Whitewing Mountain and San Joaquin Ridge, Mono County, Sierra Nevada, CA, USA. Quatern. Res. 66, 273-287. doi: 10.1016/j.yqres.2006.05.001

Moore, P. D., and Webb, J. A. (1978). An Illustrated Guide to Pollen Analysis. New York, NY: Wiley and Sons.

Morgan, C., and Pomerleau, M. M. (2012). New evidence for extreme and persistent terminal medieval drought in California's Sierra Nevada. J. Paleolimnol. 47, 707-713. doi: 10.1007/s10933-012-9590-9

Moy, C. M., Seltzer, G. O., Rodbell, D. T., and Anderson, D. M. (2002). Variability of El Niño/Southern Oscillation Activity at Millennial Timescales during the Holocene Epoch. Nature 420, 162-165. doi: 10.1038/nature01163.1

Nalepka, D., and Walanus, A. (2003). Data processing in pollen analysis. Acta Palaeobotanica 43, 125-134.

Negrini, R. M., Wigand, P. E., Draucker, S., Gobalet, K., Gardner, J. K., Sutton, M. Q., et al. (2006). The Rambla highstand shoreline and the Holocene lake-level history of Tulare Lake, California, USA. Quatern. Sci. Rev. 25, 1599-1618. doi: 10.1016/j.quascirev.2005.11.014

Norris, J., and Norris, L. (1994). History of Zaca Lake. Los Olivos, CA: Olive Press Publications.

Park, J., Byrne, R., Böhnel, H., Garza, R. M., and Conserva, M. (2010). Holocene climate change and human impact, central Mexico: a record based on maar lake pollen and sediment chemistry. Quatern. Sci. Rev. 29, 618-632. doi: 10.1016/j.quascirev.2009.10.017

Pisias, N. G. (1978). Paleoceanography of the Santa Barbara Basin During the last 8000 Years. Quatern. Res. 10, 366-384. doi: 10.1016/0033-5894(78)90027-3

Pisias, N. G. (1979). Model for paleoceanographic reconstructions of the California Current during the last 8000 years. Quatern. Res. 11, 373-386. doi: 10.1016/0033-5894(79)90081-4

Reimer, P. J., Bard, E., Bayliss, A., Beck, J. W., Blackwell, P. G., Ramsey, C. B., et al. (2013). Intcal13 and marine13 radiocarbon age calibration curves $0-50,000$ years cal BP. Radiocarbon 55, 1869-1887. doi: 10.2458/azu_js_rc.55.16947

Roark, E. B., Ingram, B. L., Southon, J., and Kennett, J. P. (2003). Holocene foraminiferal radiocarbon record of paleocirculation in the Santa Barbara Basin. Geology 31, 379. doi: 10.1130/0091-7613(2003)031<0379:HFRROP>2.0.CO;2

Rubi, L. (2013). Reconstructing Late Holocene Lake Level Using Littoral Cores from Zaca Lake, California. Fullerton: Department of Geological Sciences; California State University.

Sachse, D., Billault, I., Bowen, G. J., Chikaraishi, Y., Dawson, T. E., Feakins, S. J., et al. (2012). Molecular paleohydrology: interpreting the hydrogen-isotopic composition of lipid biomarkers from photosynthesizing organisms. Annu. Rev. Earth Planet. Sci. 40, 221-249. doi: 10.1146/annurev-earth-042711-105535

Scuderi, L. A. (1993). A 2000-year tree ring record of annual temperatures in the Sierra Nevada mountains. Science 259, 1433-1436. doi: 10.1126/science. 259.5100 .1433

Stine, S. (1994). Extreme and persistent drought in California and Patagonia during mediaeval time. Nature 369, 546-549. doi: 10.1038/369546a0

Tipping, R. (1987). The origins of corroded pollen grains at five early postglacial pollen sites in western Scotland. Rev. Palaeobot. Palynol. 53, 151-161. doi: 10.1016/0034-6667(87)90011-X

Tipping, R. (1995). Holocene landscape change at Carn Dubh, near Pitlochry, Perthshire, Scotland. J. Quatern. Sci. 10, 59-75. doi: 10.1002/jqs.3390100107

Tomescu, A. (2000). Evaluation of Holocene pollen records from the Romanian Plain. Rev. Palaeobot. Palynol. 109, 219-233. doi: 10.1016/S0034-6667(99) 00056-1

Tweddle, J. C., and Edwards, K. J. (2010). Pollen preservation zones as an interpretative tool in Holocene palynology. Rev. Palaeobot. Palynol. 161, 59-76. doi: 10.1016/j.revpalbo.2010.03.004

Twiddle, C. L., and Bunting, M. J. (2010). Experimental investigations into the preservation of pollen grains: a pilot study of four pollen types. Rev. Palaeobot. Palynol. 162, 621-630. doi: 10.1016/j.revpalbo.2010.08.003

Wilmshurst, J. M., and McGlone, M. S. (2005). Corroded Pollen and Spores as Indicators of Changing Lake Sediment Sources and Catchment Disturbance. J. Paleolimnol. 34, 503-517. doi: 10.1007/s10933-005-5476-4

Wise, E. K. (2010). Spatiotemporal variability of the precipitation dipole transition zone in the western United States. Geophys. Res. Lett. 37, 1-5. doi: 10.1029/2009GL042193

Zhao, M., Read, G., and Schimmelmann, A. (2000). An alkenone (Uk3) quasiannual sea surface temperature record (A.D. 1440 to 1940) using varved sediments from the Santa Barbara Basin. Organ. Geochem. 31, 903-917. doi: 10.1016/S0146-6380(00)00034-6

Conflict of Interest Statement: The authors declare that the research was conducted in the absence of any commercial or financial relationships that could be construed as a potential conflict of interest.

Received: 25 March 2014; accepted: 22 June 2014; published online: 10 July 2014.

Citation: Dingemans T, Mensing SA, Feakins SJ, Kirby ME and Zimmerman SRH (2014) 3000 years of environmental change at Zaca Lake, California, USA. Front. Ecol. Evol. 2:34. doi: 10.3389/fevo.2014.00034

This article was submitted to Paleoecology, a section of the journal Frontiers in Ecology and Evolution.

Copyright (C) 2014 Dingemans, Mensing, Feakins, Kirby and Zimmerman. This is an open-access article distributed under the terms of the Creative Commons Attribution License (CC BY). The use, distribution or reproduction in other forums is permitted, provided the original author(s) or licensor are credited and that the original publication in this journal is cited, in accordance with accepted academic practice. No use, distribution or reproduction is permitted which does not comply with these terms. 